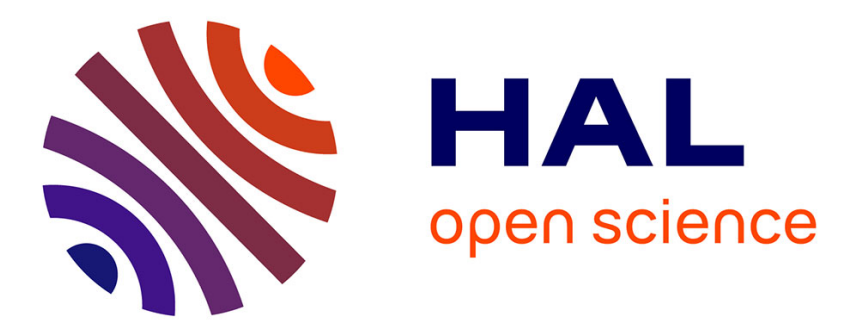

\title{
MADAGASCAR YOUNG ADULT TRANSITIONS SURVEY - Preliminary Descriptive Results
}

Catalina Herrera Almanza, Frédéric Aubery, Francesca Marchetta, Aurore

Pelissier, Harivelo Rajemison, Faly Rakotomanana, David Sahn, Kira Villa

\section{- To cite this version:}

Catalina Herrera Almanza, Frédéric Aubery, Francesca Marchetta, Aurore Pelissier, Harivelo Rajemison, et al.. MADAGASCAR YOUNG ADULT TRANSITIONS SURVEY - Preliminary Descriptive Results. 2015. halshs-01160814

\section{HAL Id: halshs-01160814 \\ https://shs.hal.science/halshs-01160814}

Preprint submitted on 8 Jun 2015

HAL is a multi-disciplinary open access archive for the deposit and dissemination of scientific research documents, whether they are published or not. The documents may come from teaching and research institutions in France or abroad, or from public or private research centers.
L'archive ouverte pluridisciplinaire HAL, est destinée au dépôt et à la diffusion de documents scientifiques de niveau recherche, publiés ou non, émanant des établissements d'enseignement et de recherche français ou étrangers, des laboratoires publics ou privés. 


\section{MADAGASCAR YOUNG ADULT TRANSITIONS SURVEY}

\section{Preliminary Descriptive Results}

Catalina Herrera Almanza, Fred Aubery, Francesca Marchetta, Aurore Pélissier, Harivelo Rajemison, Faly Rakotomanana, David Sahn, and Kira Villa

Etudes et Documents $\mathrm{n}^{\circ} 23$

November 2013 


\section{The authors}

Catalina Herrera Almanza, Cornell University

Fred Aubery, Clermont Université, Université d'Auvergne, CNRS, UMR 6587, CERDI, F-63009 Clermont Fd

Francesca Marchetta, Clermont Université, Université d'Auvergne, CNRS, UMR 6587, CERDI, F-63009 Clermont Fd

Aurore Pélissier, Clermont Université, Université d'Auvergne, CNRS, UMR 6587, CERDI, F-63009 Clermont Fd

Harivelo Rajemison, INSTAT Madagascar

Faly Rakotomanana, INSTAT Madagascar

David Sahn, Cornell University and CERDI

Kira Villa, Cornell University

Corresponding author: Francesca.Marchetta@udamail.fr

This work was supported by the LABEX IDGM+ (ANR-10-LABX-14-01) within the program "Investissements d'Avenir" operated by the French National Research Agency (ANR)

La série des Etudes et Documents du CERDI est consultable sur le site :

http://www.cerdi.org/ed

Directeur de la publication : Patrick Plane

Directeur de la rédaction : Catherine Araujo Bonjean

Responsable d'édition : Annie Cohade

ISSN : $2114-7957$

\section{Avertissement :}

Les commentaires et analyses développés n'engagent que leurs auteurs qui restent seuls responsables des erreurs et insuffisances. 


\section{Abstract}

This report provides a preliminary descriptive analysis of the Madagascar Youth Transition Survey 2012-13 (Enquête Statistique sur les itinéraires de vie des jeunes à Madagascar 201213).

This survey is the last round of a cohort panel following children from around age 8 (for about half the sample) or age 15 (for the remainder) to their early 20s. The first two surveys were mainly focused on schooling and skills and were complemented by school surveys and by community surveys. This new survey re-interviewed the cohort members and their households and updated the community information. This last round of the survey was designed to improve our understanding of the determinants and impacts of the major life course transitions-involving marriage, family, schooling, and work-of young people in Madagascar. The purpose of this report is to provide the reader with a sense of the scope and nature of the data set and with some information about the lives of young adults in Madagascar.

We acknowledge the support of The William and Flora Hewlett Foundation, the Agence inter-établissements de recherche pour le développement (AIRD) and the Agence française de développement (AFD), who funded this work as part of the DEMTREND project. The authors remain solely responsible for any errors and omissions. 


\section{Index}

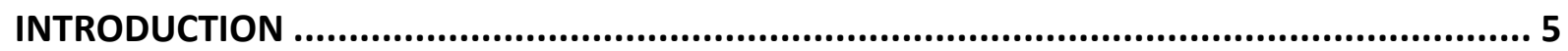

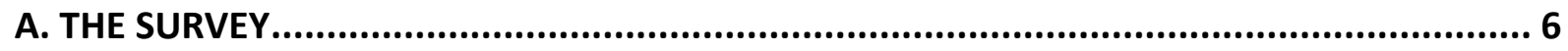

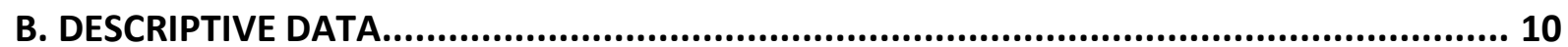

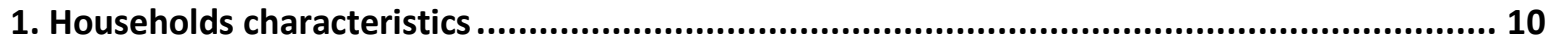

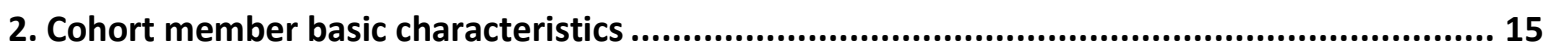

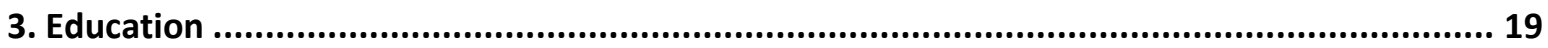

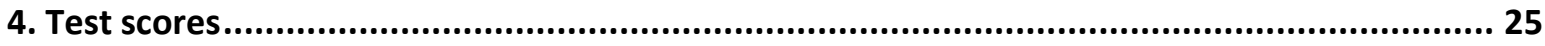

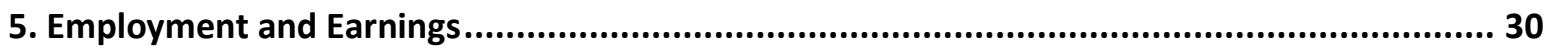

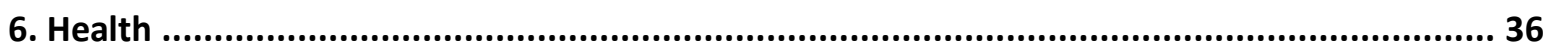

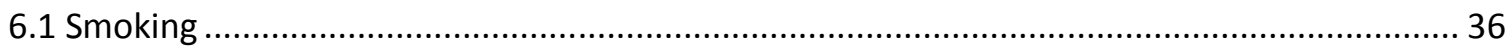

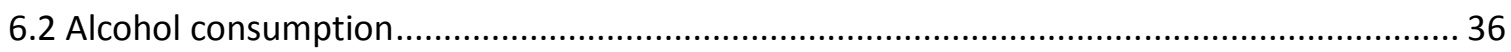

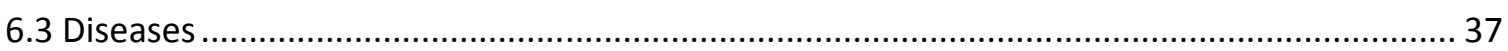

7. Fertility, Family Planning and Anthropometric Outcomes.................................................. 42

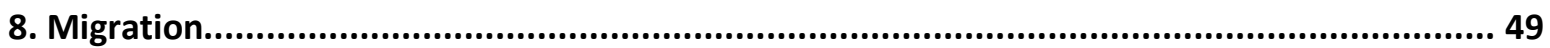

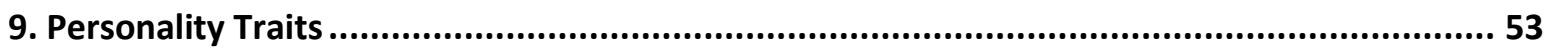

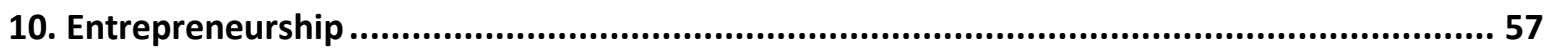

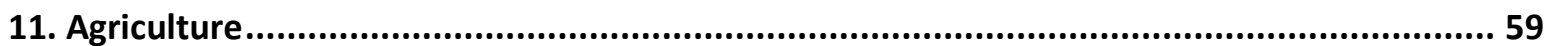




\section{INTRODUCTION}

The transition from adolescence to adulthood is a critical period in the life course. The decisions that young people and their families make regarding transitions from school into work, marriage, and parenthood will affect their opportunities and well-being for the rest of their lives. For example, given the exhaustively documented link between the level of education and individual earnings, choices about how long to continue schooling will be a major determinant of the eventual standard of living enjoyed by young men and women. For young women in particular, changes in the timing of other key transitions, such as a longer delay of marriage and motherhood, may lead to significant changes in their ability to engage in productive and remunerative work and to achieve economic and social parity with men. Delays of marriage and motherhood may also significantly reduce health risks to young women that occur through early pregnancy and heightened HIV risk from older spouses.

In developing countries, these choices also have profound implications for aggregate welfare and economic growth. If young women start families later in life and consequently have fewer dependents, more family resources will be available for savings and investment, and more female labor available to fuel economic development. This "demographic dividend" has already greatly benefited East Asia, but in other regions, notably sub-Saharan Africa, it has yet to occur. Further, there are widely documented associations of small family size and better child health and schooling outcomes, as well as between later age at marriage or childbearing and these child outcomes. Hence delays in childbearing and reduced fertility are likely to have important benefits for the well-being and healthy development of children.

Many factors condition the early life course transitions of young people: family background, the policy environment (e.g., school quality and access, family planning services or promotion), unplanned economic and health events, community norms, and incentives such as labor demand. These transitions can also be conditioned by prior decisions and behaviors that are largely or completely irreversible, such as leaving school early or having a child. These behaviors therefore are inherently dynamic and path-dependent.

For disadvantaged young people, the nature and timing of the transitions to adult roles as labor force participants, spouses, and parents will significantly determine whether they are able to escape from the poverty of their parents, or if this poverty will persist across generations. The analysis of early life course transitions is therefore closely linked to another important research area attracting considerable attention in both developed and developing countries: intergenerational economic mobility, or conversely, the intergenerational transmission of poverty. Studies from widely varying settings demonstrate strong associations between the education and incomes of parents and those of their offspring. What is less clear, especially in developing countries, is the extent to which this relationship is truly causal, and how parental and household characteristics, as opposed to the institutional environment (including for example, labor market conditions) and specific policies, shape outcomes for young people. Understanding the phenomenon of poverty persistence at the individual or household level, in turn, promises to shed light on the broader riddle of why some economies, or subgroups within an economy, are able to move out of poverty and others do not.

Potentially, research has a great deal to contribute to the design of policies to improve the lives of young people and break the transmission of poverty from one generation to the next. The need for such policy-relevant research is nowhere greater than in sub-Saharan Africa, where poverty 
is more widespread and persistent than in any other region, where levels of human capital and productivity are the lowest, and where low schooling, early marriage, and high fertility of women remains pervasive, hampering progress toward economic and social gender equality.

Our project made substantive contributions in two ways. First, we collected and made publicly available high-quality panel data from Madagascar covering young people from early primary school age to early adulthood, data that will provide the required longitudinal dimension and will be designed to permit a range of non-experimental approaches to causal inference. These surveys form a cohort panel following children from around age 8 (for about half the sample) or age 15 (for the remainder) to their early 20s. The 2003 and 2004 household surveys were complemented by community surveys and school surveys that provided detailed information on the local environment and services, including family planning services. These new surveys re-interviewed the cohort members and their households and updated the community information. The survey instrument for the second 2012-13 surveys can be viewed at:

<http://www.saga.cornell.edu/Madagascar2010/survey2010.html>

The purpose of this report is to present some descriptive statistics and related analysis of the 2012-13 survey data. We do not attempt to be comprehensive. Rather, our purpose is to provide the reader with a sense of the scope and nature of the data set and some information about the lives of young adults in Madagascar.

The remainder of this report is organized as follows: In Section A we present a brief description of the survey. This is followed, in Section B, with a presentation of descriptive statistics that correspond to the major modules or themes covered by the survey. They are as follows: Households characteristics, Cohort member basic characteristics, Education, Test scores, Employment and earnings, Health, Fertility, Family planning and anthropometric outcomes, Migration, Personality traits, Entrepreneurship, and Agriculture.

\section{THE SURVEY}

Panel household survey data, almost non-existent in developing countries a few decades ago, are now considerably more common. What remains quite rare, however, are long-term panels covering periods of more than a few years. Such data are needed to properly understand many important aspects of behavior as related to human capital accumulation and poverty transmission across generations, and impacts of policy on both issues.

As indicated, the overall project uses two periods of data collection: first, the Madagascar Study on Academic Progress and Academic Performance in Madagascar (EPSPAM) survey from 2004, and second, the Madagascar Youth Transition Survey 2012-13. In the second survey, we revisited most of the approximately 1800 households in the earlier sample, and administered specialized surveys (described below) to members in each household in the cohort of children born between 1986-1989. Some of these individuals were still living in their 2003/4 households; others will have moved away. Procedures used for finding and interviewing the latter group are described below.

The survey instruments consisted of: (1) primary surveys of the cohort members (the "target respondents"); (2) re-surveys of their originating households; and (3) an update of the community 
surveys on local infrastructure and services. We describe these survey instruments next, and then discuss procedures for tracking original respondents for the re-survey.

(1) Individual surveys of target respondents: The surveys administered to the cohort sample (aged 21-24 in 2002-13) were the primary survey instrument and covered the following main areas: education, migration, and employment histories; illness episodes and disability; marital and childbearing history; living arrangements; and assets and transfers to and from other households. The format of these modules was generally designed to be the same as in the 2003/4 surveys so as to facilitate constructing full histories using both data sets. As in the earlier survey, the data provided the basis for event history analysis of migration, work, and other life course transitions. It was designed to capture all such events and their timing since the previous survey. In some cases, additional detail relative to the earlier survey modules was gathered to obtain more information for the analysis of early life course transitions. We highlight a few of these areas:

Contraceptive use and fertility histories: Administered to the women in the target cohort sample, this new module was patterned after similar modules in Demographic and Health Surveys. It recorded knowledge and use of different methods of contraception, attitudes toward contraception, and desired family size and spacing. Fertility histories were gathered to provide information on the timing of all pregnancies and live births and use of pre- and post-natal care for each birth. Respondents were also asked about contraceptive availability (distance and travel costs to different sources), price, and periods when they could not be obtained.

Transfers and remittances: For many young men and women no longer living at home, transfers from parents and others could be an important means of support. In other cases, individuals who are working may remit funds to their originating households. To understand these flows and how they evolve, information on amounts and relationships with senders or recipients was gathered for each year the individual had been away from home (the 2003 survey recorded this information for the prior 12 months only). Information was also recorded on assets at marriage and bride price, or dowry, if relevant.

Expanded education module: Unusually detailed information was collected on the education of all cohort members to provide a complete record of individual schooling careers that could be linked to household events and characteristics, community factors, and policies. The information gathered included, among many other variables, school entry and completion or quitting ages and dates, grade repetitions and schooling interruptions and their timing, time allocated to schoolwork, education expenses, and financial assistance from schools and relatives for education purposes. Travel times and distances to schools attended, as well as schools not chosen, were recorded; the schools were identified using names and predetermined identification codes for matching to surveys of schools and the community that were also conducted.

Employment, job search, and training: We recorded standard information on work (for pay and in-kind and detailed information on work patterns for children, including detailed questions on the cohort members' job searches and desired employment, training (on and off the job), and pay. This module was designed to capture, in a level of detail not often seen in most household surveys, the economic activities and time allocation of children and youth, including household work, farm or enterprise work, and wage labor. Information included the year that work began and the time allocated to this work and to schoolwork at that time and currently for those still enrolled. 
Parents' family backgrounds: Atypically for household surveys, a range of questions was asked about the childhoods and family backgrounds of each adult in the household. These included questions on their own parents' state of health when they (the adult respondents) were 10 years old, whether their parents were absent at that time, and the year of death if the parents had died. Adult respondents were also asked a set of questions pertaining to the health and education infrastructure of the place they lived as children: presence of a primary school and lower and upper secondary schools within $5 \mathrm{~km}$ of their homes, and presence of a health clinic. Information was also collected on basic characteristics of their family's dwelling, their parents' education levels (as noted), as well as their occupations, and the number of older and younger brothers and sisters and their completed education. These data allowed for an exploration of the links between parents and children over three generations, as well as provided means of statistically identifying the impact of parental schooling and wealth on children's outcomes.

Histories of economic and health events: Many questions were asked about events affecting family and individual well-being, typically referring to the 10-year period before the survey. These events included parental death, illness, or disability of all individuals in the household; unemployment spells; enterprise failure, years of unusually bad or good harvests, and enterprise revenues; and planned and unplanned losses or acquisitions of land, livestock, and other assets. Information was collected on the year of occurrence and duration, where relevant. This information provided a year-by-year picture of major economic and health events affecting the members of the household, and was updated in the recent survey. Further, the data on exogenous shocks also provided a means of statistically identifying endogenous behaviors such as schooling duration.

Cognitive tests: Each respondent took short tests of ability in math and French. As in the 2003/4 survey, there were both oral and written math tests. As before, we developed and tested the questions for the tests in collaboration with local institutions and with the assistance of other experts in test design. There were some common items in the 2013 and 2003 tests to facilitate comparisons across surveys.

(2) Household surveys (of originating households): In the vast majority of cases, the process of locating members of the cohort involved first contacting the individual's 2003 household. Whether the target respondent was living at home or had moved away, we administered during these contacts a relatively short survey to the head or other members of the household on events and changes since the previous interview. The main motivation for these interviews was to update information on important economic or life course events experienced by the household and its members. This included information on various outcomes (education, health, marriage, and childbearing, etc.) for younger and older siblings of those in the cohort. This information was useful because, as described below, several estimation techniques as well as questions of interest rely on variation across children of different ages within a household. The questionnaires followed the basic event-history structure of the 2003/4 surveys. Since survey personnel needed to visit these households as the first step in tracking the cohort members, these household surveys raised no challenging logistical or financial issues. Of course, in many instances a target respondent was still living in the households, in which case there essentially was a single interview process.

In a number of cases, follow-up did not involve visiting the original households. This occurred when the household has moved (or dissolved), and we obtained information on the (separate) 
location of the target cohort members from other sources in the community. In these cases, information on key household events of the original household were obtained from the target respondents: these individuals, now adults and (presumably) maintaining ties with their families, know, for example, about parental illness or death, and a father's retirement or loss of employment. Respondents were also asked basic questions about their siblings, such as schooling and marital status. Enumerators administered this short module using preprinted lists of household members' identification codes and names from the 2003 survey.

(3) Community surveys: These re-surveys were implemented in each of the original 2004 clusters. They updated information on the availability and timing of introduction of various services and programs, including health and family planning services and schools, and other important developments in the community. This information was relevant for understanding the schooling and family transitions of young people occurring since the last survey. For members of the cohort who now reside elsewhere, the information gathered in these surveys obviously captured their exposure to different services only up to the period they left. We did not expect it to be feasible to gather detailed community information in the areas to which such individuals have migrated, given their dispersion to different towns and communities. However, the individual survey instruments collected some information on local services, e.g., the nearest available source of family planning services and contraception, as noted above.

\section{Tracking Respondents}

Longitudinal data are only as good as the follow-up whereby baseline participants are relocated and re-interviewed. When migration is substantial and selective, inferences about changes in household well-being over time, for example, if based only on panel analysis of those who remain in their original locations, may be very misleading. For analyzing behavioral dynamics and welfare outcomes for people who have recently entered adulthood, the hazards may be particularly acute. For these individuals, geographical mobility is often a key aspect of life course transitions, as young people move out of their parents' households (and often, away from their home communities) to marry or work. Achieving high rates of follow-up in developing country contexts was challenging but possible, as we identified adequate resources and effort to do so.

The tracking and re-interview of the 2003/4 survey respondents took place in two main stages. In the first, survey teams returned to the original sample clusters with pre-printed lists of household addresses and names of household members and their basic characteristics. If a household was no longer at its original location, inquiries were made with neighbors and community leaders as to its current location. If the household had moved to another residence in the cluster or reasonably close by, it was visited in the same initial stage. For located households, survey personnel asked about the residence of children in the cohort, now aged 21-24. Those still living in the same households (expected to be about half, as discussed below) or in other locations nearby were interviewed in this phase. Locations, addresses, and phone numbers of other target respondents were obtained for later interview. The household itself was asked to respond to a questionnaire updating information since the 2003 survey, as described above.

For target respondents who were no longer in their original locations, there were two basic situations: First, the family of the respondent had been located in the first stage and information on current residences of the target individual obtained. Second, the original household itself had moved. 
In the latter, the teams asked neighbors, community leaders or administrators, shopkeepers, and others about the location of the household, and of the target respondents specifically, as these could differ. Other panel survey experience in developing countries, including our own experience in 2003 in locating children in the original PASEC sample, suggested that it would not be difficult to obtain this information in the vast majority of cases. The second stage consisted of using this information to plan and carry out the interviews of target respondents who are in new locations.

As result of these efforts, we achieved a target attrition rate of less than 10 percent.

\section{Other Survey Implementation Issues}

The objective of collecting high quality data was achieved, due to several factors. One was the extensive experience of the institutions in conducting survey work in this and similar environments. A second was that the various institutions had worked successfully in the previous survey to produce high-quality data that yielded valuable and original analyses. A third was that this was a panel data collection, using similar instruments as before and using the same households and individuals. This had many benefits, among them that both households and communities in the panel have been sensitized to the survey process, so outreach will not be difficult.

(1) Interviewer and supervisor training: Many of the experienced individuals involved in the previous survey were available for work on the new surveys. As before, training was the key to success, requiring several weeks. We trained more personnel than were eventually selected for the work, with selection based on instructor evaluations and performance on tests at the completion of training. As in the 2003/4 surveys, the number of interviewers was kept relatively small with each team working under a highly trained supervisor.

(2) Field testing: The household and individual (cohort) questionnaires and the cognitive tests were field tested in several rural and one urban location. Adequate time was allotted for thorough review and revision of questionnaires and tests as well as the data entry program as required.

(3) Data entry and data quality: Problems of electricity supply in many rural areas made computerized data collection, otherwise advantageous, problematic. In addition, not all interviewers were comfortable with using computers to note responses. Therefore, we stayed with the standard paper-and-pencil interview, as used for the previous survey. The data entry programs were developed in Madagascar and were written with complex consistency checks that were built into the program.

\section{DESCRIPTIVE DATA}

\section{Households characteristics}

This section presents descriptive statistics on the households where cohort members live. The number of households is lower than the number of cohort members since some of them live in the same household. 
Among the 1,555 households interviewed, 697 are defined as "original households," meaning that they are the same as in 2003/4 survey, while 858 are newly established households (Table 1.1).

In terms of household size, the average number of household members is 4.69 , and the distribution is shown in Table 1.2. Approximately $60 \%$ of the sample households have four or more members, and the percentage of very large households is not negligible, with $15 \%$ per cent of the sample households having more than seven members.

Table 1.3 shows the dependency rate, which is defined as number of dependents (individuals aged less than 15 or more than 64) as compared to the number of working age members (aged between 15 and 64 years old). It ranges from zero to four, with an average of 0.49 .

As shown in Table 1.4, more than $80 \%$ of the heads of households are males. In about half of the cases, they had not attained any school diploma. Approximately $25 \%$ of household heads completed primary school, and about $17 \%$ completed college. Just a small percentage of household heads had earned a university diploma (see Table 1.5).

To initially assess the households' living standards, we analyzed some characteristics of their dwellings. The questionnaire contained a section with questions addressed to heads of the household about the conditions of their dwellings.

Concerning the type of kitchen, almost $42 \%$ of the kitchens were identified as being indoors by the heads of households; another $42 \%$ were described as outdoor kitchens, while almost $15 \%$ of the sample households do not have a kitchen in their dwellings (Table 1.6).

Table 1.7 shows that almost half of the sample households use a wood latrine platform; just a small percentage of them have a toilet seat or a squat toilet, while more than $30 \%$ of the households surveyed do not have any type of toilet at their disposal.

Concerning the water sources in the rainy season, $32 \%$ households are compelled to use water obtained from a river, lake or spring. A public tap is the source of water used by $28 \%$ of the households, followed by water from a well (without a pump), used by around $20 \%$ of the households. Less than $10 \%$ of the households have either an indoor or outdoor private tap (Table 1.8).

Table 1.9 shows that around $60 \%$ of the households use wood as the main source of fuel, while $37 \%$ use charcoal.

Table 1.10 provides information on the number of rooms in the dwelling, not including toilet and kitchen. Thirty-seven percent of the households have only single-room dwellings, and about $34 \%$ of the households live in 2-rooms dwellings. The number of rooms in a dwelling, divided by the number of persons living in the household, is a measure of the crowded conditions in which the residents live: the average in our sample is 0.56 . 
Tables

Table 1.1 Household type

\begin{tabular}{|l|rr|}
\hline & \multicolumn{2}{|c|}{ All } \\
& $\mathrm{N}$ & Percent \\
\hline Original household & 697 & 44.82 \\
New household & 858 & 55.18 \\
Total & 1,555 & 100.00 \\
\hline
\end{tabular}

Table 1.2 Household size

\begin{tabular}{|l|lr|}
\hline & \multicolumn{2}{|c|}{ All } \\
\hline 1 & 112 & Percent \\
2 & 196 & 7.20 \\
3 & 339 & 21.60 \\
4 & 245 & 15.76 \\
5 & 171 & 11.00 \\
6 & 125 & 8.04 \\
7 & 117 & 7.52 \\
8 & 91 & 5.85 \\
More than 8 & 159 & 10.23 \\
Total & 1,555 & 100.00 \\
\hline
\end{tabular}

Table 1.3 Dependency rate

\begin{tabular}{|l|rr|}
\hline & \multicolumn{2}{|c|}{ All } \\
& N & Percent \\
\hline 0 & 447 & 28.75 \\
$0<$ dep $\leq 0.5$ & 630 & 40.51 \\
$0.5<$ dep $\leq 1$ & 372 & 23.92 \\
More than 1 & 106 & 6.82 \\
Total & 1,555 & 100.00 \\
\hline
\end{tabular}

Table 1.4 Gender of household head

\begin{tabular}{|l|rr|}
\hline & \multicolumn{2}{|c|}{ All } \\
& N & Percent \\
\hline Male & 1,284 & 82.57 \\
Female & 271 & 17.43 \\
Total & 1,555 & 100.00 \\
\hline
\end{tabular}


Table 1.5 Education of household head (highest diploma attained)

\begin{tabular}{|l|rr|}
\hline & \multicolumn{2}{|c|}{ All } \\
& $\mathrm{N}$ & Percent \\
\hline No diploma & 750 & 48.23 \\
CEPE (Completed primary school) & 374 & 24.05 \\
BEPC (Completed college) & 259 & 16.66 \\
BAC (Completed high school) & 92 & 5.92 \\
DEIG/BAC+2 (2 ${ }^{\text {nd }}$ year University) & 30 & 1.93 \\
LICENCE/BAC+3 (3 ${ }^{\text {rd }}$ year University) & 32 & 2.06 \\
MAITRISE/BAC+4 (4 ${ }^{\text {th }}$ year University) & 7 & 0.45 \\
DEA/BAC+5 (5 ${ }^{\text {th }}$ year University) & 5 & 0.32 \\
PhD & 3 & 0.19 \\
Other & 3 & 0.19 \\
Total & 1,555 & 100.00 \\
\hline
\end{tabular}

Table 1.6 Type of kitchen

\begin{tabular}{|l|rr|}
\hline & \multicolumn{2}{|c|}{ All } \\
\hline Indoor kitchen & 653 & Percent \\
Outdoor kitchen & 666 & 41.99 \\
No kitchen & 229 & 42.83 \\
No information & 7 & 14.73 \\
Total & 1,555 & 0.45 \\
\hline
\end{tabular}

Table 1.7 Kind of toilet

\begin{tabular}{|l|rr|}
\hline & \multicolumn{2}{|c|}{ All } \\
\hline Toilet seat & Percent \\
Squat toilet & 33 & 2.12 \\
Latrine platform, concrete & 27 & 1.74 \\
Latrine platform, wood & 719 & 5.53 \\
Open hole & 158 & 46.24 \\
None (nature) & 522 & 33.57 \\
Others & 2 & 0.13 \\
No information & 10 & 0.51 \\
Total & 1,555 & 100.00 \\
\hline
\end{tabular}


Table 1.8 Water source, rainy season

\begin{tabular}{|l|rr|}
\hline & \multicolumn{2}{|c|}{ All } \\
& N & Percent \\
\hline Indoor tap & 75 & 4.32 \\
Public tap & 432 & 27.78 \\
Private outdoor tap & 65 & 4.18 \\
River, lake or spring & 502 & 32.28 \\
Well without pump, covered & 184 & 11.83 \\
Well without pump, not covered & 154 & 9.90 \\
Well pump & 65 & 4.18 \\
Rain water & 67 & 4.31 \\
Water seller & 1 & 0.06 \\
No information & 10 & 0.64 \\
Total & 1,555 & 100.00 \\
\hline
\end{tabular}

Table 1.9 Kind of fuel

\begin{tabular}{|l|rr|}
\hline & \multicolumn{2}{|c|}{ All } \\
\hline Wood & N & Percent \\
Charcoal & 929 & 59.74 \\
Gas & 575 & 36.98 \\
Electricity & 2 & 0.13 \\
Oil & 20 & 1.29 \\
No information & 1 & 0.06 \\
Total & 28 & 1.80 \\
\hline
\end{tabular}

Table 1.10 Number of rooms in dwelling (without kitchen and toilet)

\begin{tabular}{|l|rr|}
\hline & \multicolumn{2}{|c|}{ All } \\
\hline 1 & N & Percent \\
2 & 581 & 37.36 \\
3 & 536 & 34.47 \\
4 & 176 & 11.32 \\
5 & 167 & 10.74 \\
No information & 90 & 5.79 \\
Total & 5 & 0.32 \\
\hline
\end{tabular}




\section{Cohort member basic characteristics}

This section provides basic information on cohort members. Half of the cohort members live in the same household they lived in 2004, and half live in a new household (Table 2.1).

The sample of cohort members is almost equally split between men and women, with a slight prevalence of women, which represent $52.32 \%$ (Table 2.2). The average age of cohort members is 22 years old, and the average is the same for males and females (Table 2.3).

Table 2.4 shows that $22 \%$ of the cohort members are heads of their households, and the percentage is far higher for males (34.9\%) than for females (9.98\%). Conversely, only a small percentage of males in the survey are spouses of females identified as household head $(0.74 \%)$, while the majority of females are in this relationship with the head of the household (40.58\%). Most of the cohort members are children of the household head-almost half of the men and around $38 \%$ of the women.

Table 2.5 shows the ethnicity of the cohort members; we reported only the ethnicities that included more than $3 \%$ of the cohort members. The largest and most dominant of the groups is the Merina people; the second and third largest groups are the Betsileo and the Betsimisaraka, respectively.

Concerning marital status, almost $36 \%$ of the cohort members are married, and the percentage is far larger for women rather than for men (44\% vs. $28 \%$ ). There is quite a wide variability in the duration of the marriage (Table 2.7): most of the marriages have been contracted one or two years before the survey, but approximately $46 \%$ of cohort members have been married for more than four years, and the percentage is higher for women $(54.71 \%)$ in marriages of longer duration.

Table 2.8 and Table 2.10 show that around $43 \%$ of cohort members live with their mothers, and around $36 \%$ live with their father. Both of these groups are more largely populated by males, and this probably reflects the higher number of women who left their own households when they married.

About $15 \%$ of the mothers and $24 \%$ of the fathers of cohort members are dead. Again we observe a difference between men and women, with the data showing that men's parents are more likely to have died (Tables 2.9 and 2.11). There was also a small percentage of cohort members who declared that they did not know if their parents were still alive.

Tables

Table 2.1 Household type

\begin{tabular}{|l|rr|}
\hline & \multicolumn{2}{|c|}{ All } \\
& $\mathrm{N}$ & Percent \\
\hline Original household & 835 & 48.97 \\
Old household & 870 & 51.03 \\
Total & 1,705 & 100.00 \\
\hline
\end{tabular}


Table 2.2 Gender

\begin{tabular}{|l|rr|}
\hline & \multicolumn{2}{|c|}{ All } \\
& $\mathrm{N}$ & Percent \\
\hline Male & 813 & 47.68 \\
Female & 892 & 52.32 \\
Total & 1,705 & 100.00 \\
\hline
\end{tabular}

Table 2.3 Age

\begin{tabular}{|l|rr|rr|rr|}
\hline & \multicolumn{2}{|c|}{ All } & \multicolumn{2}{c|}{ Males } & \multicolumn{2}{c|}{ Females } \\
& $\mathrm{N}$ & Percent & $\mathrm{N}$ & Percent & $\mathrm{N}$ & Percent \\
\hline 14 & 1 & 0.06 & 0 & 0.00 & 1 & 0.11 \\
15 & 2 & 0.12 & 1 & 0.12 & 1 & 0.11 \\
17 & 3 & 0.18 & 2 & 0.25 & 1 & 0.11 \\
18 & 2 & 0.12 & 1 & 0.12 & 1 & 0.11 \\
19 & 32 & 1.88 & 10 & 1.23 & 22 & 2.47 \\
20 & 101 & 5.92 & 46 & 5.66 & 55 & 6.17 \\
21 & 517 & 30.32 & 260 & 31.98 & 257 & 28.81 \\
22 & 478 & 28.04 & 209 & 25.71 & 269 & 30.16 \\
23 & 402 & 23.58 & 199 & 24.48 & 203 & 22.76 \\
24 & 125 & 7.33 & 57 & 7.01 & 68 & 7.62 \\
25 & 35 & 2.05 & 22 & 2.71 & 13 & 1.46 \\
26 & 5 & 0.29 & 4 & 0.49 & 1 & 0.11 \\
27 & 2 & 0.12 & 2 & 0.25 & 0 & 0.00 \\
Total & 1,705 & 100.00 & 813 & 100.00 & 892 & 100.00 \\
\hline
\end{tabular}


Table 2.4 Relationship to the household head

\begin{tabular}{|l|rr|rr|rr|}
\hline & \multicolumn{2}{|c|}{ All } & \multicolumn{2}{c|}{ Males } & \multicolumn{2}{c|}{ Females } \\
& $\mathrm{N}$ & Percent & $\mathrm{N}$ & Percent & $\mathrm{N}$ & Percent \\
\hline 1. Household head & 373 & 21.88 & 284 & 34.93 & 89 & 9.98 \\
2. Spouse & 368 & 21.58 & 6 & 0.74 & 362 & 40.58 \\
3. Child & 740 & 43.40 & 399 & 49.08 & 341 & 38.23 \\
4. Adopted child & 12 & 0.70 & 9 & 1.11 & 3 & 0.34 \\
5. Grandson or granddaughter & 46 & 2.70 & 26 & 3.20 & 20 & 2.24 \\
6. Nephew or Niece & 49 & 2.87 & 27 & 3.32 & 22 & 2.47 \\
8. Brother or Sister & 40 & 2.35 & 17 & 2.09 & 23 & 2.58 \\
9. Son or Daughter-in-law & 4 & 0.23 & 2 & 0.25 & 2 & 0.22 \\
10. Brother- or Sister-in-law & 14 & 0.82 & 7 & 0.86 & 7 & 0.78 \\
12. Father- or Mother-in-Law & 2 & 0.12 & 1 & 0.12 & 1 & 0.11 \\
13. Cousin & 9 & 0.53 & 4 & 0.49 & 5 & 0.56 \\
14. Other relative & 1 & 0.06 & 0 & 0.00 & 1 & 0.11 \\
15. Adopted child & 7 & 0.41 & 7 & 0.86 & 0 & 0.00 \\
16. No relationship & 6 & 0.35 & 4 & 0.49 & 2 & 0.22 \\
No information & 34 & 1.99 & 20 & 2.46 & 14 & 1.57 \\
Total & 1,705 & 100.00 & 813 & 100.00 & 892 & 100.00 \\
\hline
\end{tabular}

Table 2.5 Ethnicity

\begin{tabular}{|l|rr|rr|rr|}
\hline & \multicolumn{2}{|c|}{ All } & \multicolumn{2}{c|}{ Males } & \multicolumn{2}{c|}{ Females } \\
& $\mathrm{N}$ & Percent & $\mathrm{N}$ & Percent & $\mathrm{N}$ & Percent \\
\hline Antandroy & 105 & 6.16 & 54 & 6.64 & 51 & 5.72 \\
Antesaka & 65 & 3.81 & 31 & 3.81 & 34 & 3.81 \\
Betsileo & 330 & 19.35 & 150 & 18.45 & 180 & 20.18 \\
Betsimisaraka & 199 & 11.67 & 92 & 11.32 & 107 & 12.00 \\
Merina & 430 & 25.22 & 225 & 27.68 & 205 & 22.98 \\
Sakalava & 103 & 6.04 & 46 & 5.66 & 57 & 6.39 \\
Sihanaka & 74 & 4.34 & 38 & 4.67 & 36 & 4.04 \\
Tanala & 60 & 3.52 & 26 & 3.20 & 34 & 3.81 \\
Tsimihety & 128 & 7.51 & 68 & 8.36 & 60 & 6.73 \\
Others & 211 & 12.38 & 83 & 10.21 & 128 & 14.35 \\
Total & 1,705 & 100.00 & 813 & 100.00 & 892 & 100.00 \\
\hline
\end{tabular}


Table 2.6 Marital status

\begin{tabular}{|l|rr|rr|rr|}
\hline & \multicolumn{2}{|c|}{ All } & \multicolumn{2}{c|}{ Males } & \multicolumn{2}{c|}{$\underline{\text { Females }}$} \\
& $\mathrm{N}$ & Percent & $\mathrm{N}$ & Percent & $\mathrm{N}$ & Percent \\
\hline Married & 622 & 36.48 & 229 & 28.17 & 393 & 44.06 \\
Single & 1,083 & 63.52 & 584 & 71.83 & 499 & 55.94 \\
Total & 1,705 & 100.00 & 813 & 100.00 & 892 & 100.00 \\
\hline
\end{tabular}

Table 2.7 Marriage duration, years

\begin{tabular}{|l|rr|rr|rr|}
\hline & \multicolumn{2}{|c|}{ All } & \multicolumn{2}{c|}{ Males } & \multicolumn{2}{c|}{ Females } \\
& N & Percent & N & Percent & N & Percent \\
\hline 0 & 2 & 0.32 & 1 & 0.44 & 1 & 0.25 \\
1 & 110 & 17.68 & 54 & 23.58 & 56 & 14.25 \\
2 & 122 & 19.61 & 65 & 28.38 & 57 & 14.50 \\
3 & 95 & 15.27 & 32 & 13.97 & 63 & 16.03 \\
4 & 94 & 15.11 & 36 & 15.97 & 58 & 14.76 \\
5 & 66 & 10.61 & 15 & 6.55 & 51 & 12.98 \\
6 & 73 & 11.74 & 14 & 6.11 & 59 & 15.01 \\
7 & 35 & 5.63 & 5 & 2.18 & 30 & 7.63 \\
8 and more & 23 & 3.71 & 6 & 2.62 & 17 & 4.33 \\
No information & 2 & 0.32 & 1 & 0.44 & 1 & 0.25 \\
Total & 622 & 100.00 & 229 & 100.00 & 393 & 100.00 \\
\hline
\end{tabular}

Table 2.8 Mother living in the same household

\begin{tabular}{|l|rr|rr|rr|}
\hline \multirow{2}{*}{} & \multicolumn{2}{|c|}{ All } & \multicolumn{2}{c|}{ Males } & \multicolumn{2}{c|}{ Females } \\
& $\mathrm{N}$ & Percent & $\mathrm{N}$ & Percent & $\mathrm{N}$ & Percent \\
\hline Yes & 729 & 42.76 & 383 & 47.11 & 346 & 38.79 \\
No & 969 & 56.83 & 426 & 52.40 & 543 & 60.87 \\
No information & 7 & 0.41 & 4 & 0.49 & 3 & 0.34 \\
Total & 1,705 & 100.00 & 813 & 100.00 & 892 & 100.00 \\
\hline
\end{tabular}

Table 2.9 Mother died

\begin{tabular}{|l|rr|rr|rr|}
\hline & \multicolumn{2}{|c|}{ All } & \multicolumn{2}{c|}{ Males } & \multicolumn{2}{c|}{ Females } \\
& $\mathrm{N}$ & Percent & $\mathrm{N}$ & Percent & $\mathrm{N}$ & Percent \\
\hline Yes & 145 & 14.95 & 82 & 19.25 & 63 & 11.60 \\
No & 824 & 85.05 & 344 & 80.75 & 480 & 88.40 \\
Total & 969 & 100.00 & 426 & 100.00 & 543 & 100.00 \\
\hline
\end{tabular}


Table 2.10 Father living in the same household

\begin{tabular}{|l|rr|rr|rr|}
\hline & \multicolumn{2}{|c|}{ All } & \multicolumn{2}{c|}{ Males } & \multicolumn{2}{c|}{ Females } \\
& $\mathrm{N}$ & Percent & $\mathrm{N}$ & Percent & $\mathrm{N}$ & Percent \\
\hline Yes & 612 & 35.89 & 335 & 41.21 & 277 & 31.05 \\
No & 1,087 & 63.75 & 475 & 58.43 & 612 & 68.61 \\
No information & 6 & 0.35 & 3 & 0.37 & 3 & 0.34 \\
Total & 1,705 & 100.00 & 813 & 100.00 & 892 & 100.00 \\
\hline
\end{tabular}

Table 2.11 Father died

\begin{tabular}{|l|rr|rr|rr|}
\hline & \multicolumn{2}{|c|}{ All } & \multicolumn{2}{c|}{ Males } & \multicolumn{2}{c|}{ Females } \\
& $\mathrm{N}$ & Percent & $\mathrm{N}$ & Percent & $\mathrm{N}$ & Percent \\
\hline Yes & 258 & 23.74 & 123 & 25.89 & 135 & 22.06 \\
No & 793 & 72.95 & 339 & 71.37 & 454 & 74.18 \\
Don't know & 26 & 2.39 & 8 & 1.68 & 18 & 2.94 \\
No information & 10 & 0.92 & 5 & 1.06 & 5 & 0.82 \\
Total & 1,087 & 100.00 & 475 & 100.00 & 612 & 100.00 \\
\hline
\end{tabular}

\section{Education}

The transition from adolescence to adulthood is a crucial period for education. ${ }^{1}$ This is the time when cohort members decide (or their parents make the decision for them) to drop out school, and as a consequence, to end their education. Table 3.1 presents this transition: in 2004, in the previous survey, $79 \%$ of the cohort members in our sample were enrolled in school while only $19 \%$ were attending school in 2011. Enrolment rate decreases with age: in 2004, $90 \%$ of 13 -year old cohort members were enrolled while only $65 \%$ of 16 -year olds were in school; in $2011,20 \%$ of the 20 -year old cohort members were enrolled while only $14 \%$ of the 24 -year old cohort members were. The enrolment rate is significantly higher among those living in richer households: in 2004 , only $6 \%$ of the cohort members living in one of the $25 \%$ poorest households of the sample were enrolled in 2011 while nearly one-third of the cohort from highest quartile of assets index were in school. Parent's education is also associated with a higher enrolment rate. Nearly one-half of the cohort members, with fathers who completed higher secondary school, was still enrolled in 2011. Table 3.2 shows enrollment rate by gender for each considered age. On average, girls were slightly less likely to be enrolled in 2004 but there were no significant difference in 2011.

Tables 3.3 and 3.4 present information concerning the last school attended and the highest grade attained in 2011 . Thirty-five percent of male cohort members and $38 \%$ of female have not

\footnotetext{
${ }^{1}$ The Malagasy school system consists of a primary cycle and a secondary cycle composed of two phases. The primary school starts at the age of 6 . Some schools offer a pre-scholar education. The primary cycle, which lasts 5 years (CP1, CP2, CE, CM1, CM2), ends with an exam at the end of the last year and a CEPE (Primary Education Completion Certificate) is acquired after succeeding to that exam. The first phase of the secondary education (lower secondary school) lasts 4 years and ends with the BEPC (Basic Secondary Education Completion Certificate). The second phase of the secondary education (High School), to last for 3 years, ends with the High School Diploma.
} 
been enrolled beyond primary school. Nearly $35 \%$ of the cohort have attended higher secondary school and above. Only $9 \%$ have continued schooling after secondary school.

Table 3.5 shows the average grade attained in 2004 and in 2011, as well as the average grade progression between the two surveys. In 2004, cohort members had reached an average of 5.19 years of schooling. In 2011, the average years of schooling attained were 7.74, and the average grade progression was 2.6 years. Interestingly, girls' and boys' performances show an opposite pattern in the two surveys. Girls performed significantly better in 2004, while boys had reached a higher grade by 2011. Grade progression is significantly higher for boys. Parents' education and household wealth are associated with better grade attainment in 2004 and in 2011 and with greater grade progression. This result suggests that differences in school achievement observed in 2004 have increased in the intervening years between the surveys. It is worth noting that the gradient in grade attainment by parents' education or household wealth is large: grade attainment is more than twice as high for households in the wealthiest quartile of the distribution that in the poorest quintile.Table 3.6

Reasons for dropping out school are presented in Tables 3.7, 3.8, and 3.9. The inability to pay for school is the main reason given by cohort members for dropping out, no matter what the last grade attained. This reason is given by $43 \%$ of the cohort. The second most frequently offered reason is related to housework (including assisting other households' members) and is given by $20 \%$ of the cohort members. This reason is more prevalent in poorer households (32\% for households in the poorest quartile) than in richer ones (14\%). The third most often provided reason is the completion of an academic cycle (17\%), suggesting that the diploma associated with the end of the cycle is a clear target for cohort members. Similarly, failing the entrance exam to the next cycle is given as a reason for dropping out by one-quarter of the cohort members who were last enrolled in higher secondary school. There is also only a small share of cohort members enrolled in college (9\%). Finally, having a bad opinion of education is the reason given by $16 \%$ of cohort members. This reason is more prevalent amongst cohort members who have attended only primary school (22\%), suggesting those with negative opinions regarding education left school early. 
Tables

Table 3.1 Enrolment rate by age, asset index, and parent's education

\begin{tabular}{|c|c|c|c|}
\hline & $\mathrm{N}$ & $\frac{\text { Enrolled in } \mathbf{2 0 0 3}}{\text { Percent }}$ & $\frac{\text { Enrolled in } \mathbf{2 0 1 1}}{\text { Percent }}$ \\
\hline Total & 1681 & 0.79 & 0.19 \\
\hline \multicolumn{4}{|l|}{ Age in 2004} \\
\hline 12 & 36 & 0.92 & 0.25 \\
\hline 13 & 158 & 0.90 & 0.30 \\
\hline 14 & 577 & 0.87 & 0.21 \\
\hline 15 & 479 & 0.77 & 0.16 \\
\hline 16 & 345 & 0.65 & 0.13 \\
\hline 17 & 27 & 0.33 & 0.14 \\
\hline \multicolumn{4}{|l|}{ Quartile of asset index in 2004} \\
\hline 1 & 350 & 0.64 & 0.06 \\
\hline 2 & 398 & 0.75 & 0.11 \\
\hline 3 & 457 & 0.80 & 0.18 \\
\hline 4 & 473 & 0.91 & 0.34 \\
\hline \multicolumn{4}{|l|}{ Father's education } \\
\hline None & 208 & 0.68 & 0.08 \\
\hline Some primary & 586 & 0.73 & 0.11 \\
\hline Completed primary & 232 & 0.76 & 0.12 \\
\hline Some lower secondary & 171 & 0.83 & 0.20 \\
\hline Completed lower secondary & 197 & 0.87 & 0.25 \\
\hline Some higher secondary & 112 & 0.94 & 0.29 \\
\hline Completed higher secondary & 114 & 0.95 & 0.50 \\
\hline Above secondary & 53 & 0.94 & 0.45 \\
\hline \multicolumn{4}{|l|}{ Mother's education } \\
\hline None & 274 & 0.71 & 0.07 \\
\hline Some primary & 583 & 0.72 & 0.13 \\
\hline Completed primary & 267 & 0.77 & 0.19 \\
\hline Some lower secondary & 207 & 0.89 & 0.22 \\
\hline Completed lower secondary & 169 & 0.88 & 0.25 \\
\hline Some higher secondary & 80 & 0.95 & 0.34 \\
\hline Completed higher secondary & 65 & 1.00 & 0.52 \\
\hline Above secondary & 23 & 1.00 & 0.70 \\
\hline
\end{tabular}


Table 3.2 Enrolment rate by gender and age in 2004

\begin{tabular}{|c|rcc|rcc|}
\hline & \multicolumn{3}{|c|}{ Male } & \multicolumn{3}{c|}{ Female } \\
\cline { 2 - 7 } Age in 2004 & \multirow{3}{*}{$\mathrm{N}$} & $\frac{\text { Enrolled in }}{\mathbf{2 0 0 4}}$ & $\frac{\text { Enrolled in }}{\mathbf{2 0 1 1}}$ & N & $\frac{\text { Enrolled in }}{\mathbf{2 0 0 4}}$ & $\frac{\text { Enrolled in }}{\mathbf{2 0 1 1}}$ \\
\hline 12 & 14 & 0.93 & 0.21 & 22 & 0.91 & 0.27 \\
13 & 66 & 0.95 & 0.30 & 92 & 0.87 & 0.29 \\
14 & 287 & 0.88 & 0.22 & 290 & 0.86 & 0.19 \\
15 & 228 & 0.82 & 0.16 & 251 & 0.74 & 0.16 \\
16 & 168 & 0.65 & 0.12 & 177 & 0.64 & 0.14 \\
17 & 12 & 0.42 & 0.17 & 15 & 0.27 & 0.12 \\
\hline Total & 775 & 0.81 & 0.19 & 847 & 0.77 & 0.18 \\
\hline
\end{tabular}

Table 3.3 Highest school attended by gender

\begin{tabular}{|l|rc|rc|}
\hline & \multicolumn{2}{|c|}{ Male } & \multicolumn{2}{c|}{ Female } \\
\cline { 2 - 5 } & N & Percent & N & Percent \\
\hline Primary school & 279 & 0.35 & 329 & 0.38 \\
Lower secondary & 221 & 0.28 & 260 & 0.30 \\
Higher secondary & 233 & 0.29 & 197 & 0.23 \\
Above secondary & 65 & 0.08 & 88 & 0.10 \\
\hline Total & 798 & 1.00 & 874 & 1.00 \\
\hline
\end{tabular}

Table 3.4 Highest grade attained by gender

\begin{tabular}{|l|rc|rc|}
\hline \multirow{2}{*}{} & \multicolumn{2}{|c|}{ Male } & \multicolumn{2}{c|}{ Female } \\
\cline { 2 - 5 } & $\mathrm{N}$ & Percent & $\mathrm{N}$ & Percent \\
\hline No grade & 15 & 0.02 & 18 & 0.02 \\
\hline CP1/T1 & 15 & 0.02 & 14 & 0.02 \\
CP2/T2 & 24 & 0.03 & 35 & 0.04 \\
CE/T3 & 63 & 0.08 & 72 & 0.08 \\
CM1/T4 & 72 & 0.09 & 77 & 0.09 \\
CM2/T5 & 105 & 0.13 & 131 & 0.15 \\
\hline 6th & 37 & 0.05 & 39 & 0.04 \\
5th & 32 & 0.04 & 50 & 0.06 \\
4th & 55 & 0.07 & 46 & 0.05 \\
3rd & 97 & 0.12 & 125 & 0.14 \\
\hline 2nd & 35 & 0.04 & 36 & 0.04 \\
1st & 53 & 0.07 & 41 & 0.05 \\
Terminale & 145 & 0.18 & 120 & 0.13 \\
\hline BAC+1 & 35 & 0.04 & 40 & 0.04 \\
BAC+2 & 17 & 0.02 & 31 & 0.03 \\
BAC+3 & 7 & 0.01 & 11 & 0.01 \\
BAC+4 & 5 & 0.01 & 5 & 0.01 \\
BAC+5 or more & 1 & 0.00 & 1 & 0.00 \\
\hline Total & 813 & 1.00 & 892 & 1.00 \\
\hline
\end{tabular}




\begin{tabular}{|c|c|c|c|}
\hline & $\frac{\text { Grade in } \mathbf{2 0 0 4}}{\text { Number of years }}$ & $\frac{\text { Grade in } 2011}{\text { Number of years }}$ & \begin{tabular}{|c|} 
Grade \\
progression \\
Number of years
\end{tabular} \\
\hline Total & 5.19 & 7.74 & 2.60 \\
\hline Male & 5.07 & 7.89 & 2.85 \\
\hline Female & 5.28 & 7.64 & 2.38 \\
\hline Rural & 4.81 & 7.10 & 2.33 \\
\hline Urban & 6.24 & 9.67 & 3.42 \\
\hline \multicolumn{4}{|l|}{ Quartile of asset index in 2003} \\
\hline 1 & 3.33 & 4.74 & 1.49 \\
\hline 2 & 4.65 & 6.76 & 2.14 \\
\hline 3 & 5.56 & 8.21 & 2.68 \\
\hline 4 & 6.65 & 10.44 & 3.77 \\
\hline \multicolumn{4}{|l|}{ Remoteness index } \\
\hline 1 & 6.13 & 9.24 & 3.12 \\
\hline 2 & 5.70 & 8.53 & 2.82 \\
\hline 3 & 4.76 & 6.83 & 2.12 \\
\hline 4 & 4.63 & 7.00 & 2.44 \\
\hline 5 & 3.83 & 5.07 & 1.31 \\
\hline \multicolumn{4}{|l|}{ Father's education } \\
\hline None & 3.63 & 5.31 & 1.77 \\
\hline Some primary & 4.44 & 6.38 & 1.98 \\
\hline Completed primary & 5.12 & 7.37 & 2.26 \\
\hline Some lower secondary & 5.78 & 8.49 & 2.74 \\
\hline Completed lower secondary & 6.18 & 9.64 & 3.50 \\
\hline Some higher secondary & 6.49 & 10.00 & 3.52 \\
\hline Completed higher secondary & 7.29 & 11.80 & 4.42 \\
\hline Above secondary & 6.89 & 11.85 & 4.89 \\
\hline \multicolumn{4}{|l|}{ Mother's education } \\
\hline None & 3.44 & 5.20 & 1.84 \\
\hline Some primary & 4.75 & 6.80 & 2.09 \\
\hline Completed primary & 5.24 & 7.65 & 2.44 \\
\hline Some lower secondary & 6.03 & 9.15 & 3.14 \\
\hline Completed lower secondary & 6.46 & 9.98 & 3.53 \\
\hline Some higher secondary & 6.67 & 10.59 & 3.90 \\
\hline Completed higher secondary & 7.32 & 12.14 & 4.78 \\
\hline Above secondary & 8.04 & 13.35 & 5.04 \\
\hline
\end{tabular}


Table 3.6 Grade attainment and grade progression by grade in 2004

\begin{tabular}{|l|c|c|}
\hline Grade in 2003 & $\begin{array}{c}\text { Grade in 2011 } \\
\text { Number of years }\end{array}$ & $\begin{array}{c}\text { Grade progression } \\
\frac{\text { since 2004 }}{\text { Number of years }}\end{array}$ \\
\hline 0 & 2.18 & 2.18 \\
1 & 3.02 & 2.07 \\
2 & 3.64 & 1.69 \\
3 & 4.35 & 1.42 \\
4 & 5.76 & 1.85 \\
5 & 7.28 & 2.33 \\
6 & 9.40 & 3.43 \\
7 & 10.80 & 3.80 \\
8 & 11.22 & 3.23 \\
9 & 11.85 & 2.85 \\
10 and more & 13.50 & 2.78 \\
\hline
\end{tabular}

Table 3.7 Reasons for dropping out school, by gender (percent)

\begin{tabular}{|l|c|c|c|}
\hline & Male & $\underline{\text { Female }}$ & $\underline{\text { Total }}$ \\
\hline IIIness / accident & 0.04 & 0.05 & 0.05 \\
Pregnancy & 0.00 & 0.13 & 0.07 \\
Cannot pay for school & 0.47 & 0.40 & 0.43 \\
Housework & 0.11 & 0.08 & 0.09 \\
Assist household's members & 0.10 & 0.11 & 0.11 \\
Involved in family business & 0.05 & 0.01 & 0.03 \\
Academic cycle completed & 0.20 & 0.15 & 0.17 \\
Bad opinion on education & 0.15 & 0.16 & 0.16 \\
Sexual harassment & 0.00 & 0.01 & 0.01 \\
Family moved & 0.00 & 0.01 & 0.01 \\
Failed at the exam & 0.08 & 0.05 & 0.06 \\
No more places open at school & 0.01 & 0.01 & 0.01 \\
Next school too distant & 0.02 & 0.02 & 0.02 \\
\hline Number of observations & 528 & 581 & 1109 \\
\hline
\end{tabular}


Table 3.8 Reasons for dropping out school, by type of last school attended (percent)

\begin{tabular}{|l|c|c|c|}
\hline \multirow{2}{*}{} & \multicolumn{3}{|c|}{ Dropped out at } \\
\cline { 2 - 3 } & primary school & $\begin{array}{c}\text { lower } \\
\text { secondary }\end{array}$ & $\begin{array}{c}\text { higher } \\
\text { secondary }\end{array}$ \\
\hline Illness / accident & 0.04 & 0.05 & 0.06 \\
Pregnancy & 0.04 & 0.10 & 0.08 \\
Cannot pay for school & 0.42 & 0.46 & 0.43 \\
Housework & 0.15 & 0.07 & 0.02 \\
Assist household's members & 0.12 & 0.13 & 0.06 \\
Involved in family business & 0.04 & 0.02 & 0.01 \\
Academic cycle completed & 0.17 & 0.19 & 0.15 \\
Bad opinion on education & 0.22 & 0.14 & 0.04 \\
Sexual harassment & 0.00 & 0.01 & 0.00 \\
Family moved & 0.01 & 0.01 & 0.01 \\
Failed at the exam & 0.00 & 0.01 & 0.26 \\
No more places open at school & 0.01 & 0.00 & 0.03 \\
Next school too distant & 0.01 & 0.01 & 0.05 \\
\hline Number of observations & 512 & 318 & 261 \\
\hline
\end{tabular}

Table 3.9 Reasons for dropping out school, by asset index quartile (percent)

\begin{tabular}{|l|c|c|c|c|}
\hline \multirow{2}{*}{} & \multicolumn{4}{|c|}{ Quartile of asset index } \\
\cline { 2 - 5 } & $\underline{\mathbf{1}}$ & $\underline{\mathbf{2}}$ & $\underline{\mathbf{3}}$ & $\underline{\mathbf{4}}$ \\
\hline Illness / accident & 0.02 & 0.03 & 0.05 & 0.09 \\
Pregnancy & 0.05 & 0.07 & 0.06 & 0.10 \\
Cannot pay for school & 0.41 & 0.43 & 0.50 & 0.37 \\
Housework & 0.17 & 0.12 & 0.03 & 0.06 \\
Assist household's members & 0.14 & 0.11 & 0.09 & 0.08 \\
Involved in family business & 0.04 & 0.04 & 0.02 & 0.02 \\
Academic cycle completed & 0.15 & 0.18 & 0.16 & 0.21 \\
Bad opinion on education & 0.24 & 0.18 & 0.12 & 0.08 \\
Sexual harassment & 0.00 & 0.00 & 0.01 & 0.01 \\
Family moved & 0.01 & 0.00 & 0.01 & 0.01 \\
Failed at the exam & 0.00 & 0.04 & 0.10 & 0.13 \\
No more places open at school & 0.00 & 0.00 & 0.02 & 0.01 \\
Next school too distant & 0.00 & 0.03 & 0.01 & 0.03 \\
\hline Number of observations & 283 & 281 & 303 & 241 \\
\hline
\end{tabular}

\section{Test scores}

Test scores provide an accurate evaluation of an individual knowledge. During the 2003/4 survey, cohort members were given tests in mathematics, French, and life skills. Math and French tests included oral and written parts. Tests were the same for every cohort member, no matter what the final grade they had attained. Scores are normalized from 0 to 1 (a score of 1 means that all answers were correct). Table 4.1 presents the correlation the various tests scores and grade 
attainment. The five scores (oral and written math test scores, oral and written French test scores, and life skills test score) are strongly correlated with each other. Not surprisingly, they are also positively and highly correlated with grade, suggesting grade attainment is a major predictor not only for academic knowledge but also for life skills. Table 4.2 presents average score by grade in 2004 . Not surprisingly, cohort members enrolled at higher grades in 2004 performed better in the 2011 tests.

Table 4.3 presents average scores by gender, parent's education, and household characteristics. For the whole sample, male cohort members performed slightly better than females, but the difference is only significant for math tests and may only be the consequence of a better mean grade attainment for males. Parent's education is strongly associated with better scores: for instance, cohort members whose fathers has no education performed 0.27 on the written French test, while cohort members whose fathers had completed higher secondary performed 0.70 . Members from wealthier households and less remote areas also received better scores. These results are not surprising if we consider them in the context of the distribution of grade attainment by quartile of asset index and by remoteness index (see Education Section 3).

In 2004, in the previous survey, cohort members were also given oral and written tests in math, French, and life skills. Previous scores are only available for 824 to 980 cohort members, depending of the kind of test. Table 4.4 presents the correlation between 2004 tests scores and the 2011 test scores. Correlations are strong, positive, and highly significant. Cohort members who performed better in the previous survey also received better scores in 2011. This result is confirmed by Tables 4.5, 4.6, and 4.7, which present average scores for the 2011 test by quintile of the scores from the previous survey. Male cohort members from the lowest 2004 French score quintile scored 0.30 , while those from the highest quintile scored 0.68 . There is no significant difference by gender. However, there is a large difference in knowledge acquisition between cohort members from rural and urban areas. Although there is no difference in math scores for members of the lowest quintiles (0.29 and 0.30 ), cohort members from urban areas scored 0.60 on average, as compared to the average rural areas of only 0.50 . 
Tables

TABLE 4.1 Correlation between tests scores and final grade attained

\begin{tabular}{|l|c|c|c|c|c|c|}
\hline & \multicolumn{5}{|c|}{ 2011 Test scores } \\
\cline { 2 - 6 } & $\frac{\text { Grade in }}{\mathbf{2 0 1 1}}$ & Oral math & $\underline{\underline{\text { Written }}}$ & Oral French & $\underline{\underline{\text { Written }}}$ & Life skills \\
\hline Grade in 2011 & 1.0 & & & & & \\
$\mathrm{~N}$ & 1705 & & & & \\
Oral math & $0.6882^{*}$ & 1.0 & & & \\
$\mathrm{~N}$ & 1550 & 1550 & & & \\
Written math & $0.6934^{*}$ & $0.7810^{*}$ & 1.0 & & \\
$\mathrm{~N}$ & 1557 & 1550 & 1557 & & \\
Oral French & $0.7142^{*}$ & $0.6815^{*}$ & $0.6971^{*}$ & 1.0 & & \\
$\mathrm{~N}$ & 1534 & 1523 & 1530 & 1534 & & \\
Written French & $0.7573^{*}$ & $0.7357^{*}$ & $0.7882^{*}$ & $0.7948^{*}$ & 1.0 & \\
$\mathrm{~N}$ & 1532 & 1523 & 1529 & 1528 & 1532 & \\
Life skills & $0.5442^{*}$ & $0.5686^{*}$ & $0.5795^{*}$ & $0.5066^{*}$ & $0.5483^{*}$ & 1.0 \\
$\mathrm{~N}$ & 1635 & 1543 & 1550 & 1528 & 1526 & 1635 \\
\hline
\end{tabular}

Table 4.2 Average scores for 2011 tests by grade level in 2004 .

\begin{tabular}{|l|c|c|c|c|c|}
\hline Grade in 2004 & Oral math & $\frac{\text { Written }}{\text { math }}$ & $\underline{\text { Oral French }}$ & $\frac{\text { Written }}{\text { French }}$ & $\underline{\underline{\text { Life skills }}}$ \\
\hline 0 & 0.15 & 0.13 & 0.13 & 0.11 & 0.38 \\
1 & 0.27 & 0.18 & 0.16 & 0.12 & 0.38 \\
2 & 0.21 & 0.16 & 0.20 & 0.16 & 0.39 \\
3 & 0.26 & 0.19 & 0.23 & 0.20 & 0.40 \\
4 & 0.36 & 0.29 & 0.37 & 0.30 & 0.45 \\
5 & 0.48 & 0.36 & 0.45 & 0.40 & 0.49 \\
6 & 0.58 & 0.44 & 0.63 & 0.52 & 0.53 \\
7 & 0.69 & 0.51 & 0.71 & 0.61 & 0.55 \\
8 & 0.71 & 0.53 & 0.78 & 0.65 & 0.55 \\
9 & 0.74 & 0.54 & 0.81 & 0.69 & 0.59 \\
10 and more & 0.84 & 0.60 & 0.92 & 0.78 & 0.61 \\
\hline
\end{tabular}


Table 4.3 Average scores for the 2011 tests by gender, parent's education and household characterictics

\begin{tabular}{|c|c|c|c|c|c|}
\hline & Oral math & $\frac{\text { Written }}{\text { math }}$ & Oral French & $\begin{array}{l}\text { Written } \\
\text { French }\end{array}$ & Life skills \\
\hline Total & 0.51 & 0.38 & 0.52 & 0.44 & 0.49 \\
\hline Male & 0.52 & 0.39 & 0.52 & 0.45 & 0.50 \\
\hline Female & 0.49 & 0.37 & 0.52 & 0.43 & 0.49 \\
\hline Rural & 0.47 & 0.35 & 0.47 & 0.39 & 0.47 \\
\hline Urban & 0.62 & 0.45 & 0.67 & 0.57 & 0.54 \\
\hline \multicolumn{6}{|l|}{ Quartile of asset index } \\
\hline 1 & 0.30 & 0.23 & 0.27 & 0.22 & 0.41 \\
\hline 2 & 0.43 & 0.32 & 0.42 & 0.34 & 0.47 \\
\hline 3 & 0.55 & 0.41 & 0.57 & 0.47 & 0.51 \\
\hline 4 & 0.67 & 0.50 & 0.72 & 0.63 & 0.55 \\
\hline \multicolumn{6}{|l|}{ Remoteness index } \\
\hline 1 & 0.60 & 0.44 & 0.64 & 0.54 & 0.54 \\
\hline 2 & 0.58 & 0.42 & 0.55 & 0.49 & 0.52 \\
\hline 3 & 0.38 & 0.31 & 0.43 & 0.35 & 0.44 \\
\hline 4 & 0.47 & 0.35 & 0.47 & 0.39 & 0.46 \\
\hline 5 & 0.28 & 0.22 & 0.23 & 0.19 & 0.42 \\
\hline \multicolumn{6}{|l|}{ Father's education } \\
\hline None & 0.35 & 0.26 & 0.31 & 0.27 & 0.42 \\
\hline Some primary & 0.42 & 0.31 & 0.40 & 0.34 & 0.46 \\
\hline Completed primary & 0.48 & 0.37 & 0.50 & 0.42 & 0.49 \\
\hline Some lower secondary & 0.53 & 0.41 & 0.57 & 0.50 & 0.51 \\
\hline Completed lower secondary & 0.65 & 0.47 & 0.68 & 0.55 & 0.53 \\
\hline Some higher secondary & 0.66 & 0.47 & 0.70 & 0.60 & 0.55 \\
\hline Completed higher secondary & 0.71 & 0.55 & 0.82 & 0.72 & 0.57 \\
\hline Above secondary & 0.73 & 0.54 & 0.81 & 0.70 & 0.59 \\
\hline \multicolumn{6}{|l|}{ Mother's education } \\
\hline None & 0.33 & 0.24 & 0.29 & 0.26 & 0.43 \\
\hline Some primary & 0.44 & 0.33 & 0.44 & 0.38 & 0.47 \\
\hline Completed primary & 0.51 & 0.38 & 0.52 & 0.43 & 0.50 \\
\hline Some lower secondary & 0.60 & 0.45 & 0.63 & 0.52 & 0.52 \\
\hline Completed lower secondary & 0.66 & 0.48 & 0.72 & 0.59 & 0.55 \\
\hline Some higher secondary & 0.65 & 0.49 & 0.71 & 0.59 & 0.55 \\
\hline Completed higher secondary & 0.79 & 0.59 & 0.81 & 0.76 & 0.58 \\
\hline Above secondary & 0.85 & 0.65 & 0.90 & 0.84 & 0.59 \\
\hline
\end{tabular}




\begin{tabular}{|c|c|c|c|c|c|c|c|c|}
\hline & & 04 test scc & & & & 1 test sco & & \\
\hline & $\underline{\text { Math }}$ & $\frac{\text { French }}{\underline{2004}}$ & $\frac{\text { Life skills }}{\underline{2004}}$ & Oral math & $\frac{\text { Written }}{\underline{\text { math }}}$ & $\underset{\text { Fral }}{\text { Oranch }}$ & $\begin{array}{l}\text { Written } \\
\text { French } \\
\end{array}$ & Life skills \\
\hline $\begin{array}{l}\text { Math } 2004 \\
\text { N }\end{array}$ & $\begin{array}{l}1.0 \\
824\end{array}$ & & & & & & & \\
\hline French 2004 & $0.6624^{*}$ & 1.0 & & & & & & \\
\hline $\mathrm{N}$ & 813 & 923 & & & & & & \\
\hline Life skills 2004 & $0.6266^{*}$ & $0.5267^{*}$ & 1.0 & & & & & \\
\hline $\mathrm{N}$ & 820 & 913 & 980 & & & & & \\
\hline Oral math & $0.4727^{*}$ & $0.3944 *$ & $0.3697^{*}$ & 1.0 & & & & \\
\hline $\mathrm{N}$ & 767 & 849 & 889 & 1550 & & & & \\
\hline Written math & $0.4718^{*}$ & $0.4007 *$ & $0.3783 *$ & $0.7810^{*}$ & 1.0 & & & \\
\hline $\mathrm{N}$ & 773 & 855 & 895 & 1550 & 1557 & & & \\
\hline Oral French & $0.4598 *$ & $0.4280 *$ & $0.3646 *$ & $0.6815^{*}$ & $0.6971 *$ & 1.0 & & \\
\hline $\mathrm{N}$ & 762 & 843 & 882 & 1523 & 1530 & 1534 & & \\
\hline Written French & $0.5171^{*}$ & $0.4867 *$ & $0.3953^{*}$ & $0.7357^{*}$ & $0.7882 *$ & $0.7948 *$ & 1.0 & \\
\hline $\mathrm{N}$ & 758 & 839 & 878 & 1523 & 1529 & 1528 & 1532 & \\
\hline Life skills & $0.4424 *$ & $0.3826 *$ & $0.3876^{*}$ & $0.5686^{*}$ & $0.5795^{*}$ & $0.5066 *$ & $0.5483 *$ & 1.0 \\
\hline $\mathrm{N}$ & 794 & 889 & 939 & 1543 & 1550 & 1528 & 1526 & 1635 \\
\hline
\end{tabular}

Table 4.5 Average 2011 math test score by quintile of the 2004 math test score

\begin{tabular}{|c|c|c|c|c|}
\hline \multirow[b]{2}{*}{2004 Math test score } & \multicolumn{4}{|c|}{2011 math test score } \\
\hline & Male & Female & Rural & Urban \\
\hline Lowest quintile & 0.31 & 0.28 & 0.29 & 0.30 \\
\hline Second quintile & 0.39 & 0.33 & 0.36 & 0.35 \\
\hline Third Quintile & 0.45 & 0.44 & 0.46 & 0.39 \\
\hline Fourth quintile & 0.56 & 0.48 & 0.52 & 0.51 \\
\hline Highest quintile & 0.59 & 0.52 & 0.50 & 0.60 \\
\hline
\end{tabular}


Table 4.6 Average 2011 French test score by quintile of the 2004 French test score

\begin{tabular}{|l|c|c|c|c|}
\hline \multirow{2}{*}{2004 French test score } & \multicolumn{4}{|c|}{ 2011 French test score } \\
\cline { 2 - 5 } Lowest quintile & $\underline{\text { Male }}$ & $\underline{\text { Female }}$ & $\frac{\text { Rural }}{0.27}$ & $\underline{\text { Urban }}$ \\
Second quintile & 0.30 & 0.26 & 0.35 \\
Third Quintile & 0.41 & 0.35 & 0.39 & 0.33 \\
Fourth quintile & 0.48 & 0.49 & 0.50 & 0.44 \\
Highest quintile & 0.60 & 0.57 & 0.56 & 0.63 \\
\hline
\end{tabular}

Table 4.7 Average 2011 life skills test score by quintile of the 2004 life skills test score

\begin{tabular}{|l|c|c|c|c|}
\hline \multirow{2}{*}{2004 Life skills test score } & \multicolumn{4}{|c|}{ 2011 life skills test score } \\
\cline { 2 - 5 } Lowest quintile & $\frac{\text { Male }}{0.44}$ & $\frac{\text { Female }}{0.40}$ & $\frac{\text { Rural }}{0.41}$ & $\underline{\underline{U} \text { Uban }}$ \\
Second quintile & 0.51 & 0.47 & 0.49 & 0.53 \\
Third Quintile & 0.50 & 0.52 & 0.50 & 0.53 \\
Fourth quintile & 0.54 & 0.53 & 0.53 & 0.55 \\
Highest quintile & 0.56 & 0.55 & 0.54 & 0.56 \\
\hline
\end{tabular}

\section{Employment and Earnings}

Employment statistics are reported in Table 5.1. Employment in the sample is high with $76 \%$ of the sample working, $14 \%$ attending school, and only $6 \%$ are neither working or in school. Unemployment is higher among females than among males, with gender-specific unemployment rates of $8.56 \%$ and $3.27 \%$, respectively. Roughly $14 \%$ of both males and females are still in school, and $80 \%$ of males and $74.33 \%$ of females are working. As can be seen in Table 5.2 , at $74 \%$, females make up a larger share of the unemployed. However the sample of those employed and students are largely equal in shares of males and females. Fifty percent of those working are males; $47 \%$ of the students in the sample are male.

Table 5.3 reports the average grade attainment in each employment category, and Figure 5.1 shows the educational distribution of individuals in each category. As would be expected, grade attainment is highest for those who are still students, with an average grade attainment of 12.10 (12.71 for males and 11.76 for females). Most current students have completed secondary school (at $34.15 \%)$, and an even larger (39.02\%) share is currently in university. Grade attainment is lowest for those currently employed, with an average grade attainment of 6.83 (7.02 for males and 6.68 for females). Although the largest share of workers (28.11\%) has only completed some primary school, the distribution is wide with a significant portion of workers having completed at least some middle (college) and some secondary school. Average grade attainment for those individuals who are neither working nor students is fairly high at 9.31 (10.81 for males and 8.73 for females). Looking at the distribution of educational status among the unemployed, there appears to be some queuing for better jobs, with the largest share (30.84\%) having completed secondary school. 
Table 5.4 describes the breakdown across occupational categories among those individuals in the sample who are working. Half of all workers (44.48\% of working males and $57.7 \%$ of working females) are employed in a family enterprise or are doing domestic work in another household not their own. Thirty percent of workers (31.91\% of males and $33.75 \%$ of females) are self-employed, and $16.58 \%$ ( $21.77 \%$ of males and $11.79 \%$ of females) are working in the public or private sector. Looking at the breakdown of main occupations across industrial sectors in Table 5.5, we see that 71\% of workers who are self-employed and $79 \%$ of those who are in a family enterprise or domestic work are working in the agricultural sector. Those who report working in the public or private sector are primarily working in a high skill occupation or a low skill/manual labor occupation.

Not surprisingly, those employed in the public and private sector have the highest grade attainment with an average grade attainment of 9.72, as reported in Table 5.6. Females in the private/public sector have a statistically significantly higher grade attainment of 10.48 than males whose average grade attainment is 9.32. However, females in family enterprises and domestic work have statically significantly less education than their male counterparts, with average grade attainments of 6.54 and 7.03, respectively. Grade attainment for the self-employed is the lowest with average grade attainment of 5.65 (5.58 for males and 5.69 for females). The educational distribution across occupational categories can be seen in Figure 5.2 .

Table 5.7 and Figure 5.3 describe individual earnings by main occupational category. In the full sample, individuals working in the private or public sector have the highest earnings while those in family and domestic work have the lowest average earnings. However, when looking at genderspecific earnings, self-employed males actually have the highest earnings while females in the public or private sector have the highest average earnings.

\section{Tables}

Table 5.1 Distribution of employment status

\begin{tabular}{|l|rr|rr|rr|}
\hline & \multicolumn{2}{|c|}{ All } & \multicolumn{2}{c|}{ Males } & \multicolumn{2}{c|}{ Females } \\
& $\mathrm{N}$ & Percent & $\mathrm{N}$ & Percent & $\mathrm{N}$ & Percent \\
\hline Unemployed & 108 & 6.07 & 27 & 3.27 & 77 & 8.56 \\
Working & 1,354 & 76.07 & 661 & 80.12 & 669 & 74.33 \\
Student & 249 & 13.99 & 112 & 13.58 & 127 & 14.11 \\
Missing & 69 & 3.88 & 25 & 3.03 & 27 & 3 \\
\hline
\end{tabular}

Table 5.2 Gender make-up of employment categories

\begin{tabular}{|l|r|r|r|}
\hline & $\underline{\text { Male }}$ & $\underline{\text { Female }}$ & Difference \\
\cline { 2 - 4 } Unemployed & 0.2596 & 0.7404 & $\mathbf{0 . 2 3 3 1}$ \\
Working & 0.4970 & 0.5030 & $-\mathbf{0 . 0 9 1 7}$ \\
Student & 0.4686 & 0.5314 & 0.0112 \\
\hline
\end{tabular}


Table 5.3 Highest grade attained by employment status

\begin{tabular}{|l|rrr|rrr|rrr|c|}
\hline & \multicolumn{3}{|c|}{ All } & \multicolumn{3}{c|}{ Males } & \multicolumn{3}{c|}{ Females } & \multicolumn{1}{c|}{ Difference } \\
& $\mathrm{N}$ & Mean & SD & $\mathrm{N}$ & Mean & SD & $\mathrm{N}$ & Mean & SD & (Female-Male) \\
\hline Unemployed & 107.00 & 9.31 & 3.21 & 26.00 & 10.81 & 2.79 & 77.00 & 8.73 & 3.19 & $\mathbf{- 2 . 0 8}$ \\
Working & 1327.00 & 6.83 & 3.52 & 653.00 & 7.02 & 3.61 & 654.00 & 6.68 & 3.44 & $\mathbf{- 0 . 3 4}$ \\
Student & 247.00 & 12.10 & 5.71 & 110.00 & 12.71 & 7.63 & 127.00 & 11.76 & 3.38 & -0.95 \\
Total & 1681.00 & 7.77 & 4.34 & 789.00 & 7.94 & 4.82 & 858.00 & 7.61 & 3.86 & -0.31 \\
\hline
\end{tabular}

Table 5.4 Main occupation of those currently working

\begin{tabular}{|l|rr|rr|rr|}
\hline & \multicolumn{2}{|c|}{ All } & \multicolumn{2}{c|}{ Males } & \multicolumn{2}{c|}{ Females } \\
& $\mathrm{N}$ & Percent & $\mathrm{N}$ & Percent & $\mathrm{N}$ & Percent \\
\hline Public/Private Sector & 214 & 16.58 & 138 & 21.77 & 75 & 11.79 \\
Self-Employed & 412 & 31.91 & 214 & 33.75 & 194 & 30.5 \\
Family Enterprise/ & 665 & 51.51 & 282 & 44.48 & 367 & 57.7 \\
Domestic Work & & & & & & \\
\hline
\end{tabular}

Table 5.5 Main occupation across industrial sectors

\begin{tabular}{|l|r|r|r|r|}
\hline & $\begin{array}{c}\frac{\text { Public/ }}{\text { Private }} \\
\text { Sector }\end{array}$ & $\begin{array}{c}\text { Self- } \\
\text { Employed }\end{array}$ & $\begin{array}{c}\frac{\text { Family }}{\text { Enterprise/ }} \\
\text { Domestic }\end{array}$ & Total \\
\hline Agriculture/ Livestock & 6 & 291 & 522 & 819 \\
Manual Labor/ Low Skill & 78 & 49 & 71 & 198 \\
Service & 33 & 68 & 63 & 164 \\
High Skill & 95 & 3 & 7 & 105 \\
Total & 212 & 411 & 663 & 1,286 \\
\hline
\end{tabular}


Table 5.6 Highest grade attained by main occupational category

\begin{tabular}{|l|rcc|rcc|rrr|c|}
\hline & \multicolumn{3}{|c}{ All } & \multicolumn{3}{c|}{ Males } & \multicolumn{3}{c|}{ Females } & Difference \\
& N & Mean & SD & N & Mean & SD & N & Mean & SD & (Female-Male) \\
\hline Public/Private Sector & 209.00 & 9.72 & 3.07 & 136.00 & 9.32 & 3.05 & 73.00 & 10.48 & 2.99 & $\mathbf{1 . 1 6}^{* * *}$ \\
Self-Employed & 406.00 & 5.65 & 3.15 & 211.00 & 5.58 & 3.32 & 191.00 & 5.69 & 2.98 & 0.11 \\
Famliy Enterprise/ & 650.00 & 6.74 & 3.38 & 279.00 & 7.03 & 3.52 & 358.00 & 6.54 & 3.26 & $\mathbf{- 0 . 4 9}^{*}$ \\
Domestic Work & & & & & & & & \\
\hline
\end{tabular}

Table 5.7 Earnings by main occupational category (1,000 Ariary)

\begin{tabular}{|c|c|c|c|c|c|c|c|c|c|c|c|c|c|}
\hline & $\mathrm{N}$ & Mean & Median & SD & $\mathrm{N}$ & Mean & Median & SD & $\mathrm{N}$ & Mean & Median & SD & $\begin{array}{c}\text { Difference } \\
\text { (Female- } \\
\text { Male) }\end{array}$ \\
\hline Public/Private Sector & 212 & 193.27 & 1040 & 445.65 & 138 & 207.69 & 1200 & 456.78 & 73 & 168.64 & 800 & 428.33 & -39.05 \\
\hline Self-Employed & 409 & 180.27 & 330 & 848.10 & 213 & 222.43 & 384 & 106.33 & 192 & 137.22 & 178 & 52.64 & -85.22 \\
\hline $\begin{array}{l}\text { Family Enterprise/ } \\
\text { Domestic Work }\end{array}$ & 659 & 82.55 & 0 & 459.69 & 282 & 120.22 & 0 & 639.35 & 362 & 52.64 & 0 & 250.08 & -67.58 \\
\hline Total & 1280 & 132.11 & 100 & 611.19 & 633 & 173.69 & 320 & 780.09 & 627 & 92.05 & 0 & 379.35 & -81.64 \\
\hline
\end{tabular}

Note: Earnings are reported in Ariary. 1,000 Ariary is 0.45 US\$ (7 November 2013) 


\section{Figures-Employment and Earnings}
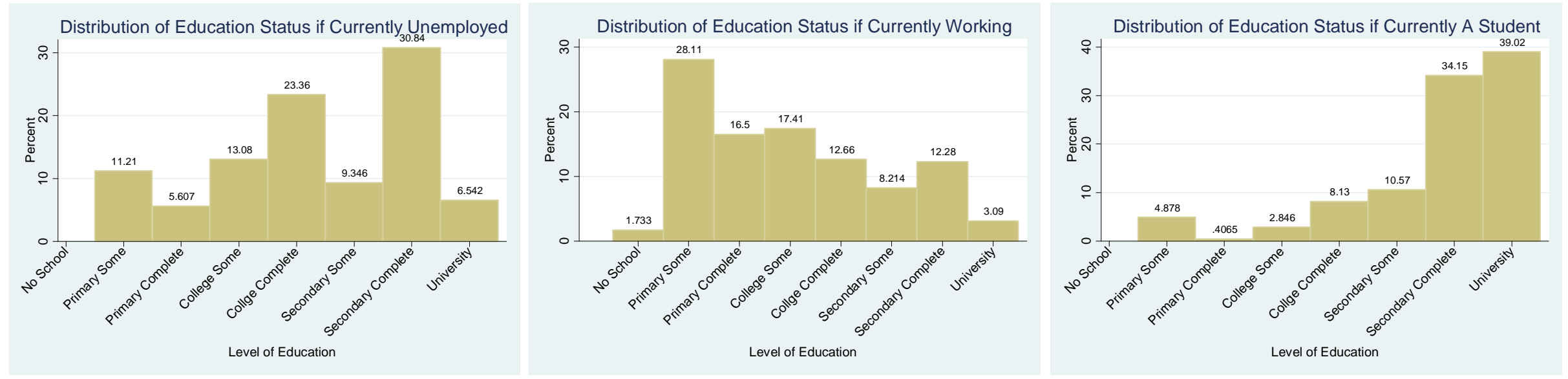

Fig. 5.1 Distribution of educational attainment by Employment status

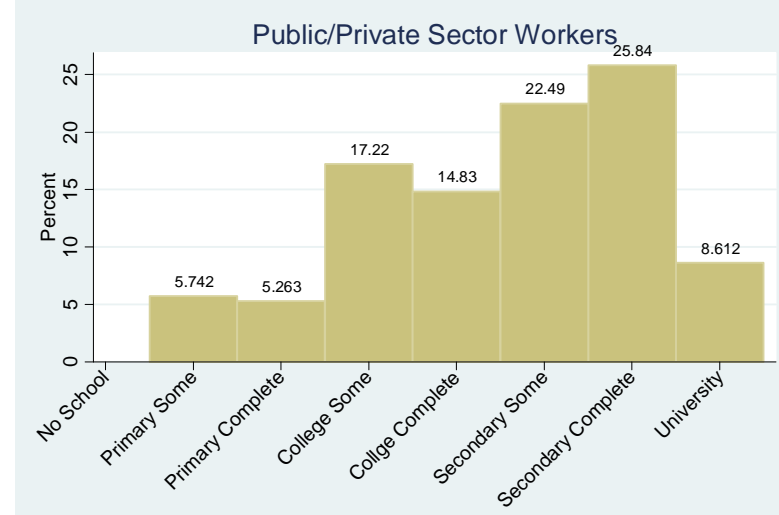

Level of Education
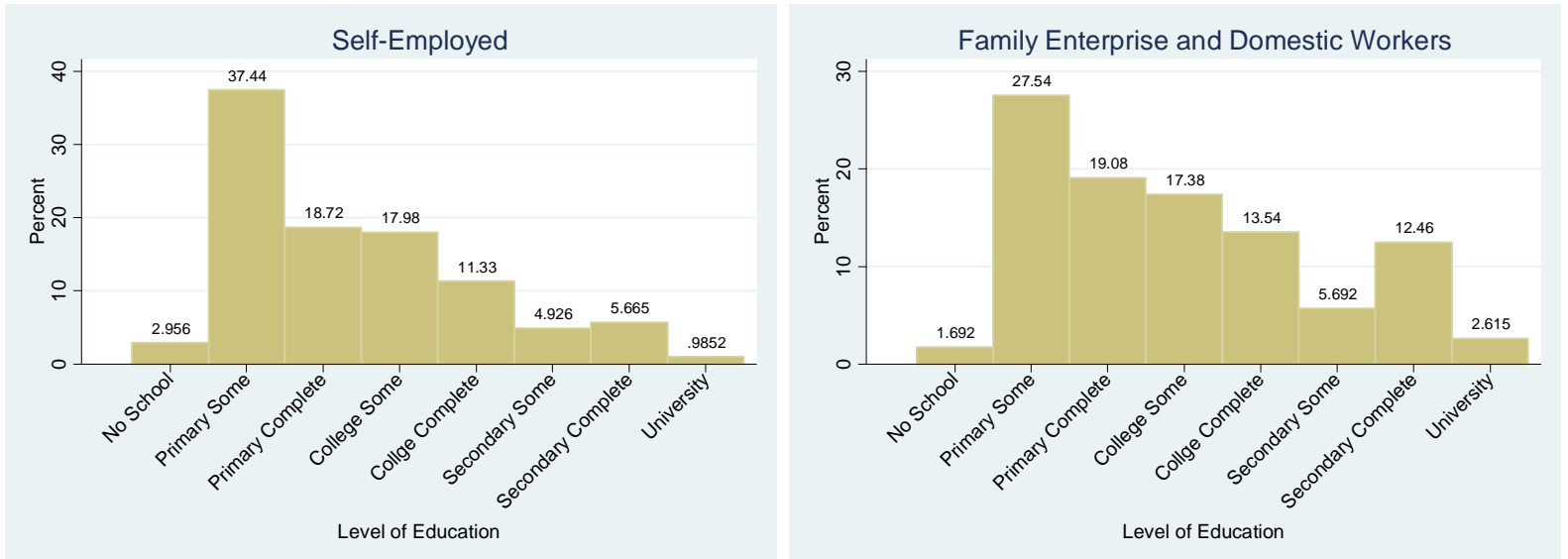

Fig. 5.2 Distribution of educational attainment by occupational category 

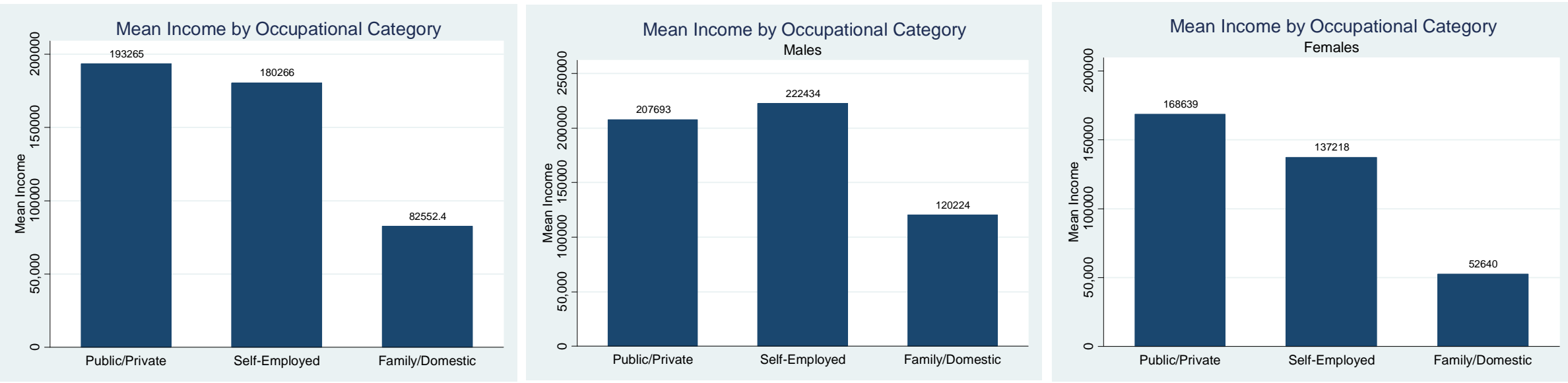

Fig.5.3 Earnings by main occupational category 


\section{Health}

\section{Smoking}

In our sample, 200 cohort members are currently smoking, or $12 \%$ of the sample. Smokers are mainly men $(96.5 \%)$, with women representing only $3.5 \%$ of smokers. One quarter of men are currently smoking, but the vast majority of women are not (Table 6.1).

The vast majority of smokers smoke between one and five cigarettes per day in the entire sample (65\%); the gender difference is males $(65.80 \%)$ and females $(42.86 \%)$. For females, it should be noted that the same proportion of them (42.86\%) declared that they smoked between 6 and 10 cigarettes per day (Table 6.2).

In our sample, $39 \%$ have a family member who smoked during their childhood, most often identified as the father. Patterns between males and females are quite similar. Additionally, $56 \%$ of smokers reported a family member who smoked during their childhood while only $36 \%$ of non-smokers did. Again, it was mainly the fathers who smoked during the childhood of cohort members (Table 6.3).

Overall, smokers started smoking at 18 years old, with no significant statistical difference between males and females (Table 6.4).

The distribution of educational level with regard to smoking status shows that a higher proportion of highly educated cohort members ("Lycee" completed and University or DEUG and more) are non-smokers rather than smokers (Figure 6.1).

\section{Alcohol consumption}

In our sample, 253 cohort members report consuming alcohol, or $15 \%$ of the sample. Consumers are mainly men (90\%). Twenty-eight percent of men consume alcohol, whereas the vast majority of women do not (Table 6.5).

On average, cohort members consume 9 beers per month and 16 glasses of alcohol. Patterns are quite different when considering women and men separately. Women consume more glasses of alcohol per month than men: 25 vs. 15. Men consume more beers than women: 9 vs. 5 (Table 6.6).

In our sample, $48 \%$ of cohort members have a family member who consumed alcohol during their childhood. This family member was most often identified as the father (37\%). Patterns between males and females are quite similar. Also, $65 \%$ of alcohol consumers have a family member who consumed alcohol during their childhood, whereas only $45 \%$ of non-consumers did. Again, it was mainly the fathers who consumed alcohol during the childhoods of cohort members (Table 6.7).

Overall, current alcohol consumers started drinking alcohol at 18 years old, with no significant statistical differences between males and females (Table 6.8). 
The distribution of education level with regard to alcohol consumption status shows that a higher proportion of highly educated cohort members ("Lycee" completed and University or DEUG and more) do not drink alcohol (Figure 6.2).

\section{Disease}

One hundred thirty-nine cohort members, or $8 \%$ of the sample, at the time of the survey, report suffering from disease. The patterns are quite similar among men and women: $8 \%$ of men and $9 \%$ of women report illness. Slightly more women than men report affliction at the time of the survey (78 women, or $56 \%$ vs. 61 men, or $44 \%$ ) (Table 6.9).

Among cohort members who report that they are suffering from a disease at the time of the survey, the main type of disease reported (except for the category of "others") is diarrhea or digestive problems (17\%). The conclusion is similar when considering males and females separately. Tuberculosis and breathing problems represent $11 \%$ of the disease declared. It is the second most frequent type of illness declared by men. In comparison, this illness category represents only $8 \%$ of diseases declared by women. Malaria represents $7 \%$ of the diseases declared by the sick cohort members, with a similar incidence observed between males and females (Table 6.10).

Nine percent of the sick cohort members have suffered from specified illness since their birth. Twenty-one percent report suffering for less than a year, 23\% between 1 and 5 years, 29\% between 5 and 10 years, and $13 \%$ for more than 10 years (but not since birth) (Table 6.11).

Additionally, 121 cohort members, or $7.10 \%$ of the sample, declared that, during the previous 10 years, they had one or more serious illnesses or injuries that prevented them from doing their usual activities for one month or more.

\section{Tables}

Table 6.1 Current smoking status

\begin{tabular}{|l|rr|rr|rr|}
\hline & \multicolumn{2}{|c|}{ All } & \multicolumn{2}{c|}{ Males } & \multicolumn{2}{c|}{ Females } \\
& $\mathrm{N}$ & Percent & $\mathrm{N}$ & Percent & $\mathrm{N}$ & Percent \\
\hline Yes & 200 & 11.73 & 193 & 23.74 & 7 & 0.78 \\
No & 1505 & 88.27 & 620 & 76.26 & 885 & 99.22 \\
Total & 1705 & 100.00 & 813 & 100.00 & 892 & 100.00 \\
\hline
\end{tabular}


Table 6.2 Tobacco consumption per day

\begin{tabular}{|l|rr|rr|rr|}
\hline & \multicolumn{2}{|c|}{ All } & \multicolumn{2}{c|}{ Males } & \multicolumn{2}{c|}{ Females } \\
& N & Percent & N & Percent & N & Percent \\
\hline 1-5 cigarettes & 130 & 65.00 & 127 & 65.80 & 3 & 42.86 \\
6-10 cigarettes & 56 & 28.00 & 53 & 27.46 & 3 & 42.86 \\
Less than 1 pack & 5 & 2.50 & 5 & 2.59 & 0 & 0.00 \\
1 pack & 7 & 3.50 & 6 & 3.11 & 1 & 14.29 \\
1-2 packs & 1 & 0.50 & 1 & 0.52 & 0 & 0 \\
2 or more packs & 1 & 0.50 & 1 & 0.52 & 0 & 0 \\
Total & 200 & 100.00 & 193 & 100.00 & 7 & 100.00 \\
\hline
\end{tabular}

Table 6.3 Family smoking behavior during childhood

\begin{tabular}{|c|c|c|}
\hline & \multicolumn{2}{|c|}{ All } \\
\hline & $\mathrm{N}$ & Percent \\
\hline All & & \\
\hline A family member smoked ( $N=1705)$ & 657 & 38.53 \\
\hline Father smoked ( $\mathrm{N}=1705)$ & 440 & 25.81 \\
\hline Mother smoked ( $\mathrm{N}=1705)$ & 33 & 1.94 \\
\hline Others family members smoked (1705) & 346 & 20.29 \\
\hline Males & & \\
\hline A family member smoked $(\mathrm{N}=813)$ & 331 & 40.71 \\
\hline Father smoked ( $\mathrm{N}=813)$ & 222 & 27.31 \\
\hline Mother smoked $(\mathrm{N}=813)$ & 19 & 2.34 \\
\hline Others family members smoked $(\mathrm{N}=813)$ & 173 & 21.28 \\
\hline Females & & \\
\hline A family member smoked $(\mathrm{N}=892)$ & 326 & 36.55 \\
\hline Father smoked $(\mathrm{N}=892)$ & 218 & 24.44 \\
\hline Mother smoked ( $\mathrm{N}=892)$ & 14 & 1.57 \\
\hline Others family members smoked ( $\mathrm{N}=892)$ & 191 & 21.41 \\
\hline Smokers & & \\
\hline A family member smoked $(\mathrm{N}=200)$ & 112 & 56.00 \\
\hline Father smoked $(\mathrm{N}=200)$ & 77 & 38.50 \\
\hline Mother smoked ( $\mathrm{N}=200)$ & 7 & 3.50 \\
\hline Others family members smoked $(\mathrm{N}=200)$ & 57 & 28.50 \\
\hline Non-smokers & & \\
\hline A family member smoked ( $\mathrm{N}=1505)$ & 545 & 36.21 \\
\hline Father smoked ( $N=1505)$ & 363 & 24.12 \\
\hline Mother smoked $(\mathrm{N}=1505)$ & 26 & 1.73 \\
\hline Others family members smoked ( $N=1505)$ & 2989 & 19.20 \\
\hline
\end{tabular}


Table 6.4 Age of initiation of smokers

\begin{tabular}{|c|c|c|c|c|c|c|c|c|c|c|}
\hline & \multicolumn{3}{|c|}{ All } & \multicolumn{3}{|c|}{ Males } & \multicolumn{3}{|c|}{ Females } & \multirow{2}{*}{$\begin{array}{c}\text { Difference } \\
\text { (Males-Females) }\end{array}$} \\
\hline & $\mathrm{N}$ & Mean & SD & $\mathrm{N}$ & Mean & SD & $\mathrm{N}$ & Mean & SD & \\
\hline Age of initiation & 197 & 18 & 2.29 & 191 & 18.00 & 2.23 & 6 & 17 & 3.87 & 0.8387 (n.s.) \\
\hline
\end{tabular}

Table 6.5 Current alcohol consumption status

\begin{tabular}{|l|rr|rr|rr|}
\hline & \multicolumn{2}{|c|}{ All } & \multicolumn{2}{c|}{ Males } & \multicolumn{2}{c|}{ Females } \\
& $\mathrm{N}$ & Percent & $\mathrm{N}$ & Percent & $\mathrm{N}$ & Percent \\
\hline Yes & 253 & 14.84 & 227 & 27.92 & 26 & 2.91 \\
No & 1452 & 84.16 & 586 & 72.08 & 866 & 97.09 \\
Total & 1705 & 100.00 & 813 & 100.00 & 892 & 100.00 \\
\hline
\end{tabular}

Table 6.6 Beer and alcohol consumption per month

\begin{tabular}{|l|rrr|rrr|rrr|}
\hline & \multicolumn{3}{|c|}{ All } & \multicolumn{3}{c|}{ Males } & \multicolumn{3}{c|}{ Females } \\
& $\mathrm{N}$ & Mean & SD & $\mathrm{N}$ & Mean & SD & $\mathrm{N}$ & Mean & SD \\
\hline Nb of beers & 164 & 8.96 & 23.05 & 151 & 9.29 & 23.96 & 13 & 5.14 & 4.94 \\
Nb of glasses of alcohol & 164 & 16.16 & 27.33 & 150 & 15.31 & 26.47 & 14 & 25.26 & 35.17 \\
\hline
\end{tabular}


Table 6.7 Family alcohol consumption during childhood

\begin{tabular}{|c|c|c|}
\hline & \multicolumn{2}{|r|}{ All } \\
\hline & $\mathrm{N}$ & Percent \\
\hline All & & \\
\hline A family member consumed alcohol $(\mathrm{N}=1705)$ & 823 & 48.27 \\
\hline Father consumed alcohol $(\mathrm{N}=1705)$ & 628 & 36.83 \\
\hline Mother consumed alcohol $(\mathrm{N}=1705)$ & 77 & 4.52 \\
\hline Others family members consumed alcohol (1705) & 296 & 17.36 \\
\hline Males & & \\
\hline A family member consumed alcohol $(\mathrm{N}=813)$ & 413 & 50.80 \\
\hline Father consumed alcohol $(\mathrm{N}=813)$ & 302 & 37.15 \\
\hline Mother consumed alcohol $(\mathrm{N}=813)$ & 41 & 5.04 \\
\hline Others family members consumed alcohol $(\mathrm{N}=813)$ & 156 & 19.19 \\
\hline Females & & \\
\hline A family member consumed alcohol $(\mathrm{N}=892)$ & 410 & 45.96 \\
\hline Father consumed alcohol $(\mathrm{N}=892)$ & 326 & 36.55 \\
\hline Mother consumed alcohol $(\mathrm{N}=892)$ & 36 & 4.04 \\
\hline Others family members consumed alcohol ( $\mathrm{N}=892)$ & 140 & 15.70 \\
\hline Alcohol consumers & & \\
\hline A family member consumed alcohol $(\mathrm{N}=253)$ & 165 & 65.22 \\
\hline Father consumed alcohol $(\mathrm{N}=253)$ & 126 & 49.80 \\
\hline Mother consumed alcohol $(\mathrm{N}=253)$ & 14 & 5.53 \\
\hline Others family members consumed alcohol $(\mathrm{N}=253)$ & 70 & 27.67 \\
\hline Non-alcohol consumers & & \\
\hline A family member consumed alcohol ( $N=1452)$ & 658 & 45.32 \\
\hline Father consumed alcohol $(\mathrm{N}=1452)$ & 502 & 34.57 \\
\hline Mother consumed alcohol ( $N=1452)$ & 63 & 4.34 \\
\hline Others family members consumed alcohol ( $N=1452)$ & 226 & 15.56 \\
\hline
\end{tabular}

Table 6.8 Age of initiation of smokers

\begin{tabular}{|c|c|c|c|c|c|c|c|c|c|c|}
\hline & \multicolumn{3}{|c|}{ All } & \multicolumn{3}{|c|}{ Males } & \multicolumn{3}{|c|}{ Females } & \multirow{2}{*}{$\begin{array}{c}\text { Difference } \\
\text { (Males-Females) }\end{array}$} \\
\hline & $\mathrm{N}$ & Mean & SD & $\mathrm{N}$ & Mean & SD & $\mathrm{N}$ & Mean & SD & \\
\hline Age of initiation & 237 & 18 & 2.32 & 218 & 18 & 2.31 & 19 & 19 & 2.31 & 0.8122 \\
\hline
\end{tabular}


Table 6.9 Current disease

\begin{tabular}{|l|rr|rr|rr|}
\hline & \multicolumn{2}{|c|}{ All } & \multicolumn{2}{c|}{ Males } & \multicolumn{2}{c|}{ Females } \\
& $\mathrm{N}$ & Percent & $\mathrm{N}$ & Percent & $\mathrm{N}$ & Percent \\
\hline Yes & 139 & 8.15 & 61 & 7.50 & 78 & 8.74 \\
No & 1566 & 91.85 & 752 & 92.50 & 814 & 921.26 \\
Total & 1705 & 100.00 & 813 & 100.00 & 892 & 100.00 \\
\hline
\end{tabular}

Table 6.10 Type of current disease

\begin{tabular}{|l|rr|rr|rr|}
\hline & \multicolumn{2}{|c|}{ All } & \multicolumn{2}{c|}{ Males } & \multicolumn{2}{c|}{ Females } \\
& N & Percent & N & Percent & N & Percent \\
\hline Diarrhea, digestive problems & 23 & 16.55 & 12 & 19.67 & 11 & 14.10 \\
Mental or/and physical disabilities & 16 & 11.51 & 7 & 11.48 & 9 & 11.54 \\
Heart, blood pressure problems & 13 & 9.35 & 5 & 8.20 & 8 & 10.25 \\
Tuberculosis/breathing problems & 15 & 10.79 & 9 & 14.75 & 6 & 7.69 \\
Malaria & 10 & 7.19 & 4 & 6.56 & 6 & 7.69 \\
Flu & 11 & 7.91 & 3 & 4.92 & 8 & 10.25 \\
Others & 51 & 36.69 & 21 & 34.43 & 30 & 38.46 \\
Total & 139 & 100.00 & 61 & 100.00 & 78 & 100.00 \\
\hline
\end{tabular}

Table 6.11 Duration of current disease

\begin{tabular}{|l|rr|rr|rr|}
\hline & \multicolumn{2}{|c|}{$\begin{array}{l}\text { All } \\
\text { Less than a year }\end{array}$} & \multicolumn{2}{c|}{ Males } & \multicolumn{2}{c|}{ Females } \\
1-5 years & 11 & 20.75 & 6 & 31.58 & 5 & 14.71 \\
5-10 years & 12 & 22.64 & 4 & 21.05 & 8 & 23.53 \\
More than 10 years (but not since the birth) & 18 & 28.57 & 7 & 36.84 & 11 & 32.35 \\
Since birth & 7 & 13.20 & 1 & 5.26 & 6 & 17.65 \\
Total & 5 & 9.43 & 1 & 5.26 & 4 & 11.76 \\
& 53 & 100.00 & 19 & 100.00 & 34 & 100.00 \\
\hline
\end{tabular}


Figures-Health
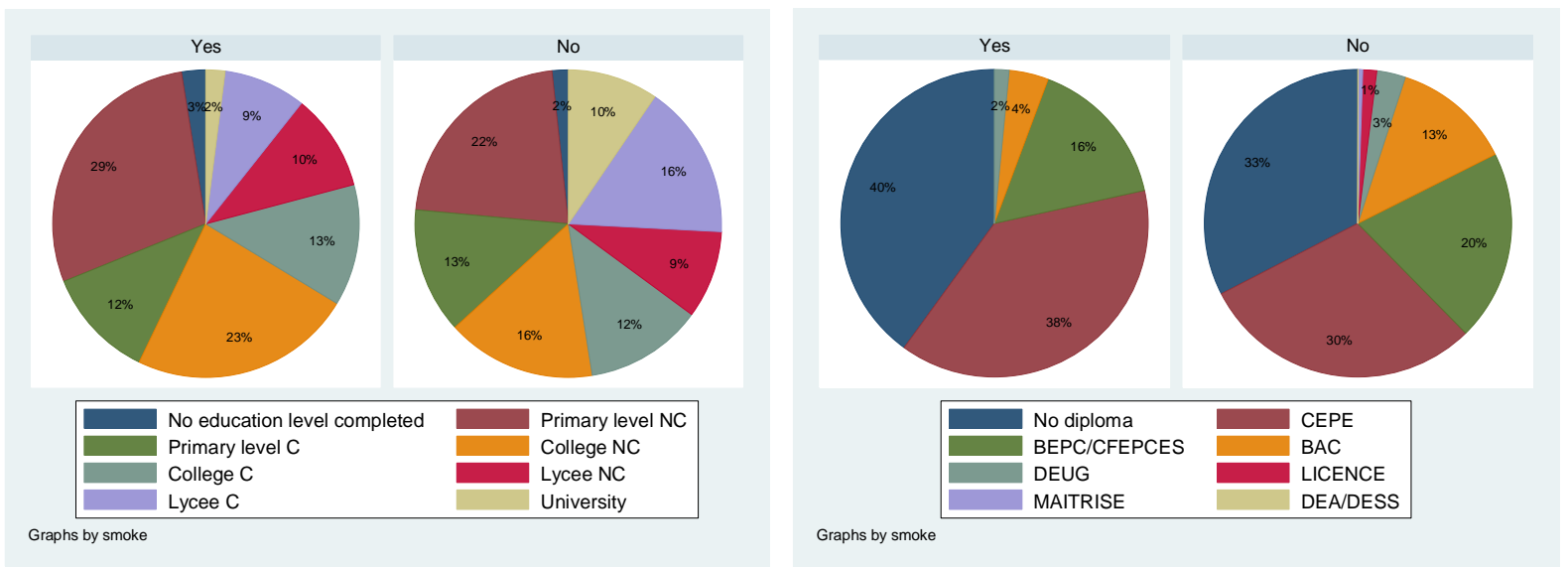

Note: C for completed, NC for not completed.

Fig. 6.1 Education level according to smoking status
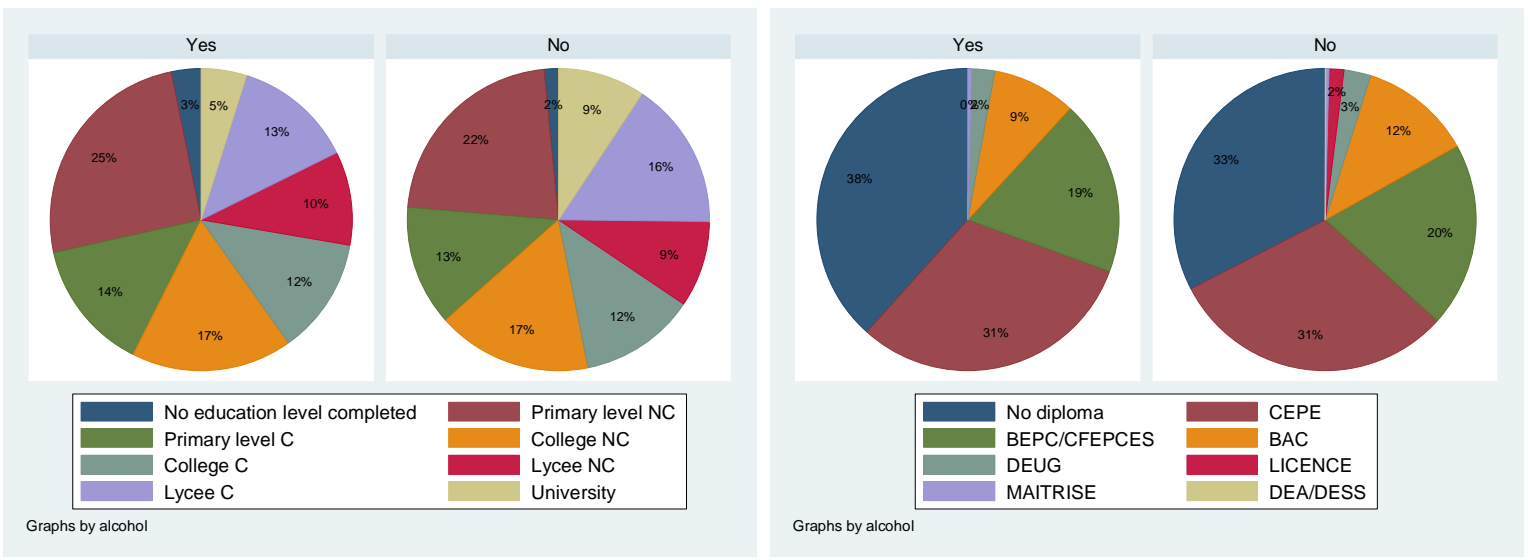

Fig. 6.2 Education level according to alcohol consumption status

\section{Fertility, Family Planning and Anthropometric Outcomes}

We have fertility information for 859 women in the cohort sample. Table 7.1 shows that $54 \%$ (466) of the women in the sample are mothers. The average age of first birth is 18 years (standard deviation 2.12), which is consistent with the 2009 Demographic Health Survey (DHS) at the national level. Almost $60 \%$ of themothers have only one child while $32 \%$ report having two, and the rest of the group report having three or more. Additionally, only $6 \%$ of the women are currently pregnant, and $32 \%$ desire to get pregnant. 
Table 7.2 shows that $31.2 \%$ of the young women in the cohort sample use family planning, modern or traditional methods. Among the young women who are not currently using any method, only $9 \%$ used family planning five years prior to the survey. These numbers reflect a very low use of family planning methods which is consistent with the 2009 DHS data: the prevalence rate of family planning among married women between 15 and 49 years old is $29 \%$ at the national level. In addition, Table 7.2 shows that only $20 \%$ of women in the sample have been visited by community family planning workers during the last year.

We also analyzed the use of family planning with respect to women's years of education and their highest level of schooling. Interestingly, we observe that women who are not using family planning have on average 7.77 years of education, whereas their counterparts who use some form of contraception have 7.2 years. Although this difference is not large in magnitude, it is statistically significant. With respect to level of education, we do not observe major differences during the progression through primary school, but we do observe that women who are not users of family planning have achieved higher levels of education after secondary school. For instance, while $11 \%$ of non-users have superior/university studies, only $3 \%$ of the users are at this level (Table 7.3).

This relationship of education and family planning use could be related to the fact that, in Madagascar, women who use contraceptive methods are already mothers and have received less education, as we will describe later. In fact, Table 7.4 indicates that there is a larger group of family planning users among the mothers compared to the non-mothers. This is consistent with the fact that almost $40 \%$ of women in Madagascar use family planning for the first time after they have already had at least one child (DHS 2009).

The results from community questionnaires, shown in Table 7.4, describe access to family planning services among young women. Access is defined as the availability of family planning services in the community where the young woman lives. This is not a woman's self-reported information, but rather based on answers given by community leaders about social infrastructure and services at the community level. We observe that, on average, the group of mothers has less access to family planning services, specifically, to pills and condoms than the group of non-mothers.

Table 7.5 shows the educational outcomes for ever mothers and non-mothers. Although $34 \%$ of the non-mothers still attend school, only $3 \%$ of the ever mothers are enrolled. These patterns are consistent with the years of education completed by the two groups, as also shown in Table 7.5. While the group of mothers completed 6.2 years of schooling, the corresponding completion figure for nonmothers is 9.25. This difference is reflected in the data on the progression through school. Among the group of mothers, only 5\% completed upper secondary, although this percentage is almost five times larger than for the non-mothers. Also, $17 \%$ of the women who have not yet had their first birth have some university education, whereas this percentage among young mothers is negligible.

This difference in the school attainment between mothers and non-mothers is also reflected in the test score performance. The share of young women in the upper quintiles of the math and French test scores distribution is far greater for those who are not yet mothers in 2012 than for those women who have given birth by 2012 (Figures 7.1a and 7.1b). 
To illustrate the timing of women's education and fertility decisions, we calculate the difference between the age of awareness of conception and age of dropping out of school, and classify the young women according to the timing of these two decisions (Figure 7.2). We find that almost $24 \%$ of the sample, or $46 \%$ of the young mothers became pregnant while they were in school. In contrast, $30 \%$ of the girls drop out of school, but they have not become pregnant by the time of the survey. It is noteworthy that $27 \%$ of the young women drop out much sooner than their first birth, indicating that there is no overlap between their fertility and education decisions. Finally, we also observe that only $16 \%$ of the young women are still attending school at the time of the survey are "non-mothers." A very negligible proportion of the sample (2\%) are " mothers" and currently enrolled in school, which suggests the difficulty of continuing education once ae young woman has had her first child.

\section{Children's Anthropometric Outcomes}

To construct the anthropometric outcomes, we use the height, age, and weight information of the children included in the fertility module, who are sons and daughters of the female cohort members. We restrict the anthropometric measurements for those children aged 5 or younger.

Table 7.6 shows the height-for-age (HAZ) score for the children in the sample. There are not statistically significant differences between girls and boys. This is a long-term child health indicator widely used to measure chronic malnutrition. We observe in Table 6 that $48 \%$ of the children are stunted (i.e., the child HAZ is below $-2 \mathrm{SD}$ ). This is consistent with the national level of $50 \%$ stunting as measured by the 2009 DHS. The severe stunting (i.e., the percentage of children with HAZ below -3 SD) is 31\%.

Table 7.7 shows the weight-for-age (WAZ) indicator for children in the sample. Girls present a better indicator than boys, and this difference is statistically significant. Indeed, although $19 \%$ of the girls are underweight (i.e., the child WAZ is below -2 SD), this percentage is $28 \%$ among boys.

Finally, Table 7.8 shows the weight-for-height (WAH) indicator. There are statistically significant differences between girls and boys; girls show better performance in this health indicator. The percentage of children who are wasted (i.e., children with WAH below -2 SD) is $17 \%$, and among girls this percentage decreases to $11 \%$.

\section{Tables}

Table 7.1 Fertility outcomes among young women

\begin{tabular}{|l|rr|rr|rr|}
\hline \multirow{2}{*}{} & \multicolumn{2}{|c|}{ Mother } & \multicolumn{2}{c|}{ Currently pregnant } & \multicolumn{2}{c|}{ Desire to be pregnant } \\
\cline { 2 - 6 } & $\mathbf{N}$ & Percent & N & Percent & N & Percent \\
\hline Yes & 466 & 54.25 & 56 & 6.52 & 282 & 32.83 \\
No & 393 & 45.75 & 784 & 91.27 & 510 & 92.20 \\
Missing & & & 19 & 2.21 & 67 & 7.80 \\
Total & 859 & 100.00 & 859 & 100.00 & 859 & 100.00 \\
\hline
\end{tabular}


Table 7.2 Young women's reported family planning use

\begin{tabular}{|c|c|c|c|c|c|c|}
\hline & \multicolumn{2}{|c|}{$\begin{array}{l}\text { Current family } \\
\text { planning use (FP) }\end{array}$} & \multicolumn{2}{|c|}{$\frac{\frac{\text { If not current, family }}{\text { planning use } 5 \text { years }}}{\text { ago }}$} & \multicolumn{2}{|c|}{$\begin{array}{l}\frac{\text { In the last } 12 \text { months }}{\text { have some FP }} \\
\text { workers visited you? }\end{array}$} \\
\hline & $\mathbf{N}$ & Percent & $\mathbf{N}$ & Percent & $\mathbf{N}$ & Percent \\
\hline Yes & 268 & 31.2 & 55 & 9.31 & 170 & 19.79 \\
\hline No & 591 & 68.8 & 521 & 88.16 & 678 & 98.72 \\
\hline Missing & & & 15 & 2.54 & 11 & 1.28 \\
\hline Total & 859 & 100.0 & 591 & 100.00 & 859 & 100.00 \\
\hline
\end{tabular}

Table 7.3 Family planning use by women's education

\begin{tabular}{|l|r|r|r|}
\hline & \multicolumn{1}{|c|}{$\begin{array}{c}\text { Users, family } \\
\text { planning }\end{array}$} & $\begin{array}{c}\text { Non-users, } \\
\text { pamily } \\
\text { planning }\end{array}$ & \multicolumn{1}{|c|}{ Total } \\
\hline Years of schooling & 7.2 & 7.77 & 7.59 \\
\% Highest education level & & & \\
None & 1.49 & 2.03 & 1.86 \\
Some primary & 20.52 & 22.84 & 22.12 \\
Completed primary & 16.79 & 14.21 & 15.02 \\
Some college & 22.39 & 12.01 & 15.25 \\
Completed college & 15.3 & 14.21 & 14.55 \\
Some lycee & 8.58 & 8.8 & 8.73 \\
Completed lycee & 11.19 & 14.38 & 13.39 \\
Superior & 3.73 & 11.51 & 9.08 \\
Total & 100.00 & 100.00 & 100.00 \\
N & 268 & 591 & 859 \\
\hline
\end{tabular}


Table 7.4 Access and family planning use among young women

\begin{tabular}{|l|r|r|r|}
\hline & Non-mothers & \multicolumn{1}{|c|}{ mother } & \multicolumn{1}{|c|}{ All } \\
\hline \% Family planning Use & 18.07 & 42.27 & 31.2 \\
\% 2012 FP services access & 91.09 & 80.9 & 85.56 \\
\% 2012 pills access & 83.21 & 73.61 & 78 \\
\% 2012 Condoms access & 84.48 & 69.10 & 76.10 \\
\hline N & 393 & 466 & 859 \\
\hline
\end{tabular}

Note: The differences between non-mother and ever mothers for the FP variables are statistically significant at $1 \%$ level. Source: Herrera and Sahn (2013).

Table 7.5 Education for mothers and Non-mothers

\begin{tabular}{|l|c|c|c|}
\hline & Mothers & Non-mothers & All \\
\hline \% School enrolment & 3.27 & 34.00 & 17.39 \\
Years of education & 6.20 & 9.25 & 7.60 \\
& $(3.18)$ & $(3.74)$ & $(3.77)$ \\
\% Completed primary & 18.67 & 10.69 & 15.02 \\
\% Completed lower secondary & 14.81 & 14.25 & 14.55 \\
\% Completed upper seconday & 4.94 & 23.41 & 13.39 \\
\% Some university & 1.93 & 17.56 & 9.08 \\
No of observations & 466 & 393 & 859 \\
\hline
\end{tabular}

Notes: Standard deviations in parentheses.

Differences between groups are statistically significant at $1 \%$.

Table 7.6 Height-for-Age (HAZ) for children under age of 5

\begin{tabular}{|l|c|c|c|}
\hline & \multicolumn{1}{|c|}{ Boys } & \multicolumn{1}{c|}{ Girls } & Total \\
\hline HAZ Score & -1.73 & -1.71 & -1.72 \\
Stunting (\%) & 0.46 & 0.49 & 0.48 \\
Severe Stunting (\%) & 0.30 & 0.32 & 0.31 \\
N & 270 & 247 & 517 \\
\hline
\end{tabular}

Stunting is defined as the percentage of children with HAZ score below -2 SD.

Severe Stunting is defined as the percentage of children with HAZ score below -3 SD. 
Table 7.7 Weight-for-Age (WAZ) for children under age of 5

\begin{tabular}{|l|c|c|c|}
\hline & Boys & $\underline{\text { Girls }}$ & $\underline{\text { Total }}$ \\
\hline WAZ Score & -0.98 & -0.51 & -0.76 \\
Underweight (\%) & 0.28 & 0.19 & 0.23 \\
$\mathrm{~N}$ & 270 & 247 & 517 \\
\hline
\end{tabular}

Underweight is defined as the percentage of children with HAZ score below -2 SD

Table 7.8 Weight-for-Height/Length for children under age of 5

\begin{tabular}{|l|c|c|c|}
\hline & Boys & Girls & Total \\
\hline WAH Z-Score & 0.04 & 0.68 & 0.34 \\
Wasting (\%) & 0.23 & 0.11 & 0.17 \\
N & 264 & 243 & 507 \\
\hline
\end{tabular}

Wasting is defined as the percentage of children with WAH score below -2 SD 


\section{Figures}

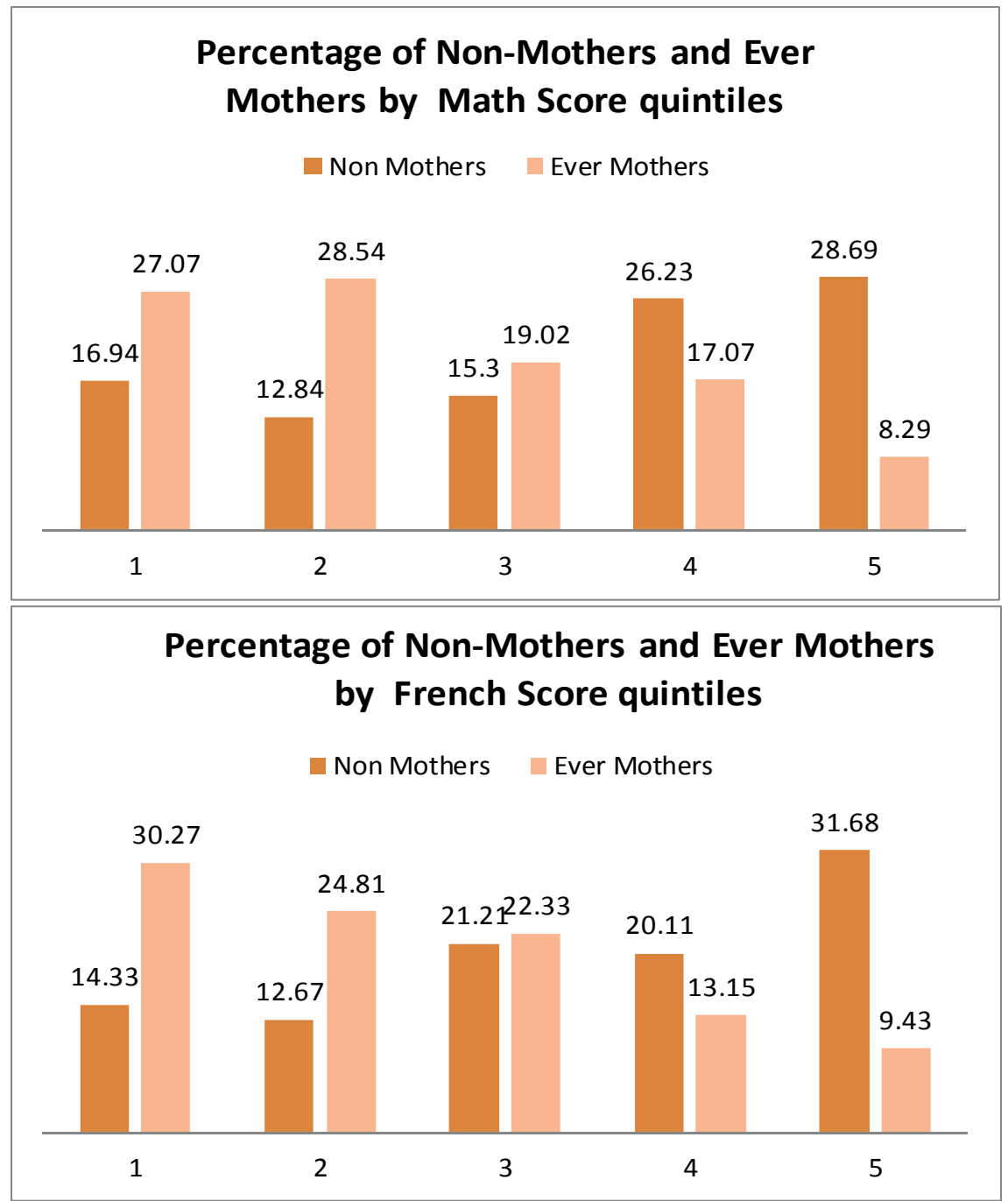

Source :Herrera and Sahn (2013)

Figure 7.1a Percentage of non-mothers and ever mothers by math score quintiles

Figure 7.1b Percentage of non-mothers and ever mothers by French score quintiles 
5.

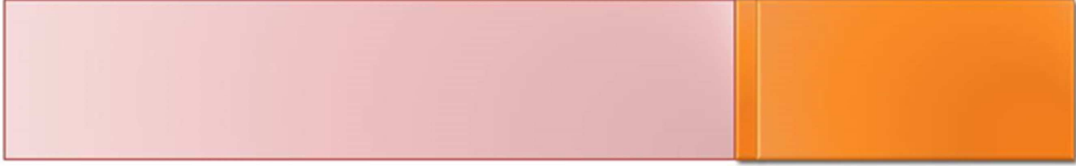

Drop out, non moms $30 \%$

4.

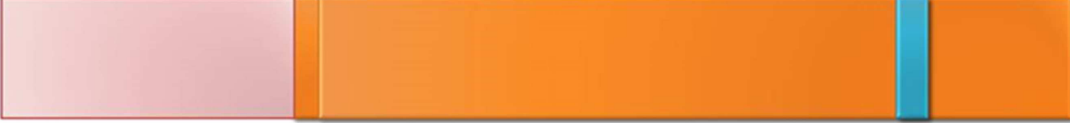

Drop out, later moms $27 \%$

3.

17.6

Pregnant in School

$24 \%$

Currently enrolled non-moms. $16 \%$

2.

Currently enrolled

1.

17.9 moms $2 \%$,

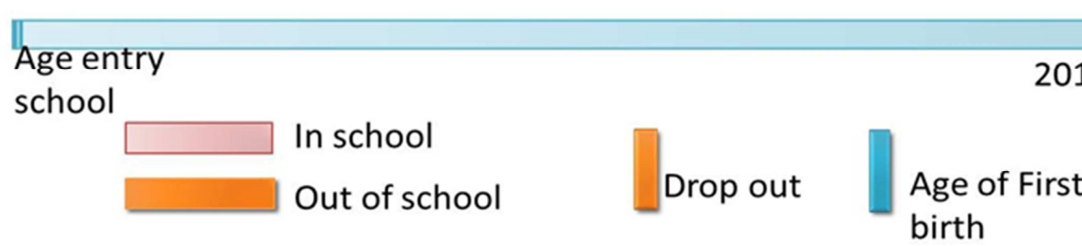

Source: Herrera and Sahn (2013)

Figure 7.2 School enrollment, dropping out, and pregnancy

\section{Migration}

Nearly one third of cohort members have migrated. The majority of these, or two-thirds, live alone, outside their original household. We consider different types of migration by the extent of the displacement. Starting from the initial place of residence, in most cases, it is (i) a migration within the district or (ii) while changing districts, migration is within the same province. Starting from no migration, the migration rate decreases as the distance of destination. Next, these categories are distinguished by the level of education attained by the members of this cohort, the types of employment of those who are in the workforce and their status in their jobs. Indeed, the education supply as well as employment opportunities depend on the communities and motivate substantial displacement (Table 8.1)

\section{Highest level of education}

Migration, far from one's place of origin, has allowed some members of the cohort, to achieve a relatively high level of education: secondary education. Thus, among those who migrated, $29 \%$ of those who changed province reached or completed their education at the university level, while $30 \%$ of those 
who stayed in the same district have completed only high school. In contrast, nearly three-quarters of those who have never migrated completed at most the college level (Figure 8.1)

Two-thirds of those who have migrated are currently employed, which reinforces the idea that migration is related, in large part, to looking for work. In addition, one-fifth of our population is still studying. This proportion increases to $40 \%$ for those who moved to another province, consistent with the fact that the availability of higher education institutions requires these displacements (Figure 8.2)

We distinguish two types of work activity performed by those who migrate. On the one hand, services (trade, transport, etc.) predominantly concern those who have moved to another province. Agriculture is the primary concern for those who remain in their same district. A large majority of migrants (44\%) work in family businesses (agricultural or service-related). Only a quarter of these migrants work in their own businesses, created by themselves. The remaining work is in private companies or in the public sector (Tables 8.2, 8.3, 8.4).

Tables

Table 8.1 Migration status, by gender

\begin{tabular}{|l|r|r|r|r|r|r|}
\hline & \multicolumn{2}{|c|}{ Male } & \multicolumn{2}{c|}{ Female } & \multicolumn{2}{c|}{ Total } \\
\cline { 2 - 7 } & \multicolumn{1}{|c}{ N } & Percent & N & Percent & N & Percent \\
\hline Within district & 108 & 13.06 & 140 & 15.57 & 248 & 14.37 \\
Within province. between districts & 85 & 10.28 & 100 & 11.12 & 185 & 10.72 \\
Between provinces & 45 & 5.44 & 52 & 5.78 & 97 & 5.62 \\
No information & 5 & 0.60 & 6 & 0.67 & 11 & 0.64 \\
Has not migrated & 584 & 70.62 & 601 & 66.85 & 1185 & 68.66 \\
& & & & & & \\
Total & 827 & 100.00 & 899 & 100.00 & 1726 & 100.00 \\
\hline
\end{tabular}

Table 8.2 Industrial sector by category of migration

\begin{tabular}{|l|c|c|c|c|c|}
\hline & $\frac{\text { Agriculture / }}{\text { livestock }}$ & $\frac{\begin{array}{c}\text { Manual } \\
\text { labor/low }\end{array}}{\underline{\text { Skill }}}$ & $\underline{\text { Service }}$ & High skill & Total \\
\hline Within district & 52.97 & 4.32 & 41.62 & 1.08 & 100.00 \\
Between districts & 25.69 & 4.59 & 61.47 & 8.26 & 100.00 \\
Between provinces & 19.15 & 4.26 & 70.21 & 6.38 & 100.00 \\
No information & 60.00 & 0.00 & 40.00 & 0.00 & 100.00 \\
Total & 39.88 & 4.34 & 51.73 & 4.05 & 100.00 \\
\hline
\end{tabular}


Table 8.3 Main occupational categories among the employed

\begin{tabular}{|l|c|c|c|c|}
\hline & $\begin{array}{c}\text { Public / private } \\
\text { Sector }\end{array}$ & Self-employed & $\begin{array}{c}\text { Family enterprise } \\
\text { / domestic work }\end{array}$ & Total \\
\hline Within district & 23.78 & 31.89 & 44.32 & 100.00 \\
Between districts & 36.70 & 17.43 & 45.87 & 100.00 \\
Between provinces & 21.28 & 40.43 & 38.30 & 100.00 \\
Total & 27.57 & 28.45 & 43.99 & 100.00 \\
\hline
\end{tabular}

Table 8.4 Employment status by category of migration

\begin{tabular}{|c|c|c|c|c|c|c|c|c|c|c|}
\hline & \multicolumn{3}{|c|}{ Male } & \multicolumn{3}{|c|}{ Female } & \multicolumn{3}{|c|}{ All } & \multirow[t]{2}{*}{ All } \\
\hline & Unempl'd & Working & Student & Unempl'd & Working & Student & Unempl'd & Working & Student & \\
\hline Within district & 4 & 85 & 19 & 20 & 100 & 17 & 24 & 185 & 36 & 245 \\
\hline districts & 11 & 54 & 15 & 18 & 55 & 24 & 29 & 109 & 39 & 177 \\
\hline $\begin{array}{l}\text { Between } \\
\text { provinces }\end{array}$ & 3 & 23 & 17 & 7 & 24 & 21 & 10 & 47 & 38 & 95 \\
\hline No information & & 3 & & 2 & 2 & 2 & 2 & 5 & 2 & 9 \\
\hline $\begin{array}{l}\text { Has not } \\
\text { migrated }\end{array}$ & 19 & 507 & 53 & 61 & 482 & 56 & 80 & 989 & 109 & 1178 \\
\hline Total & 37 & 672 & 104 & 108 & 663 & 120 & 145 & 1335 & 224 & 1704 \\
\hline
\end{tabular}


Table 8.5 Distribution of the cohort members in 2003 and 2012 at region level, by status of migration

\begin{tabular}{|c|c|c|c|c|c|}
\hline & \multicolumn{3}{|c|}{2003} & \multicolumn{2}{|c|}{2012} \\
\hline & $\frac{\frac{\text { Have not }}{\text { emigrated }}}{\text { (a) }}$ & $\frac{\begin{array}{c}\text { Have } \\
\text { emigrated }\end{array}}{\text { (b) }}$ & $\frac{\text { Total }}{(a)+(b)}$ & $\frac{\stackrel{\text { Are }}{\text { immigrants }}}{\text { (c) }}$ & $\frac{\text { Total }}{(\mathrm{a})+(\mathrm{c})}$ \\
\hline ANALAMANGA & 90 & 31 & 121 & 76 & 166 \\
\hline VAKINANKARATRA & 92 & 50 & 142 & 44 & 136 \\
\hline ITASY & 20 & 0 & 20 & 4 & 24 \\
\hline BONGOLAVA & 94 & 22 & 116 & 8 & 102 \\
\hline MATSIATRA AMBONY & 116 & 24 & 140 & 31 & 147 \\
\hline AMORON I MANIA & 85 & 50 & 135 & 25 & 110 \\
\hline VATOVAVY FITOVINANY & 67 & 29 & 96 & 23 & 90 \\
\hline IHOROMBE & 0 & 0 & 0 & 5 & 5 \\
\hline ATSIMO ATSINANANA & 25 & 20 & 45 & 16 & 41 \\
\hline ATSINANANA & 69 & 39 & 108 & 61 & 130 \\
\hline ANALANJIROFO & 25 & 15 & 40 & 1 & 26 \\
\hline ALAOTRA MANGORO & 86 & 49 & 135 & 32 & 118 \\
\hline BOENY & 46 & 14 & 60 & 25 & 71 \\
\hline SOFIA & 36 & 4 & 40 & 3 & 39 \\
\hline BETSIBOKA & 21 & 4 & 25 & 0 & 21 \\
\hline MELAKY & 54 & 13 & 67 & 7 & 61 \\
\hline ATSIMO ANDREFANA & 92 & 58 & 150 & 63 & 155 \\
\hline ANDROY & 47 & 24 & 71 & 15 & 62 \\
\hline ANOSY & 15 & 5 & 20 & 4 & 19 \\
\hline MENABE & 0 & 0 & 0 & 6 & 6 \\
\hline DIANA & 17 & 10 & 27 & 23 & 40 \\
\hline SAVA & 100 & 47 & 147 & 36 & 136 \\
\hline Total & 1197 & 508 & 1705 & 508 & 1705 \\
\hline
\end{tabular}




\section{Figures}

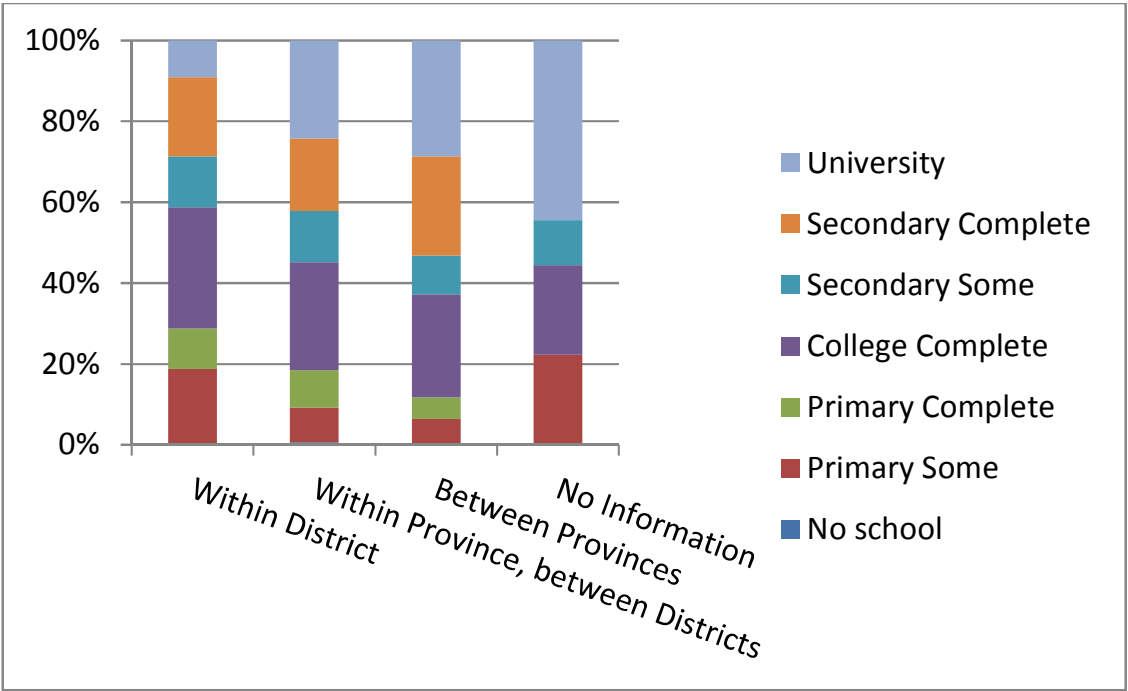

Fig. 8.1 Educational attainment by migration status

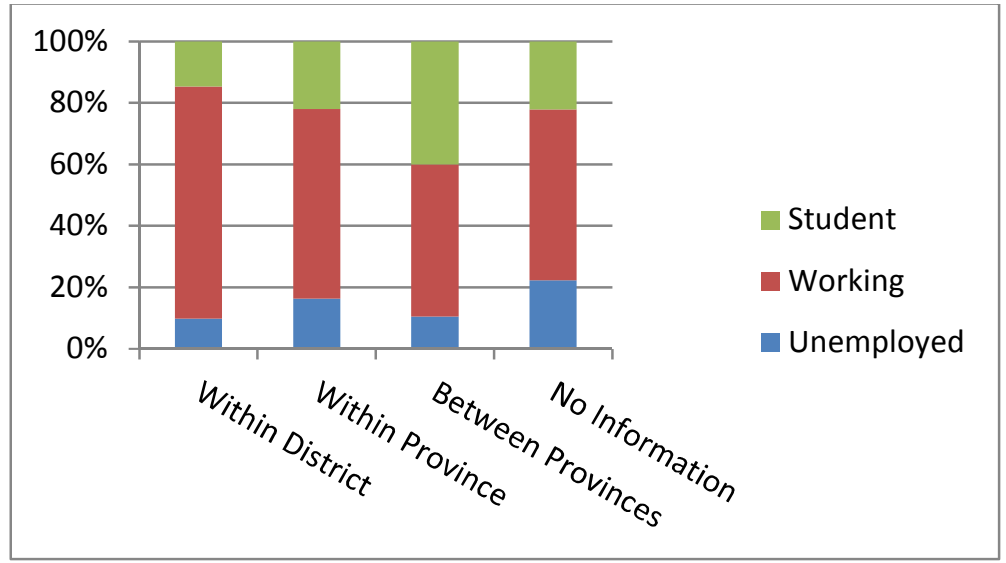

Fig. 8.2 Employment status by migration status

\section{Personality Traits}

Table 9.1 describes the distribution of standardized personality traits by gender in the sample. In all traits (conscientiousness, extroversion, openness to experience, and agreeableness) except neuroticism, males have significantly higher levels than females. However, males are significantly less neurotic than females. 
Table 9.2 describes personality traits by school enrollment status. Individuals currently enrolled in school have significantly higher levels of conscientiousness, extroversion, openness to experience, and agreeableness. Table 9.3 and Figure 9.1 illustrates these same personality traits with respect to the last school an individual was enrolled (Figure 9.1 excludes kindergarten since only one individual falls in that category). Levels of conscientiousness, extroversion, and openness to experience all increase with the level of education, while neuroticism decreases with level of education. Agreeableness also increases with education from primary school to the university; however, it is also highest for those who were last enrolled in community school.

Table 9.4 and Figure 9.2 describe personality traits with respect to the main occupational category. High levels of conscientiousness, openness to experience, and extroversion are found among students and individuals working in the public and private sector. Neuroticism is low among individuals in these categories. The unemployed also have high levels of conscientiousness and extroversion but lower levels of openness to experience. Self-employed individuals have personality traits that are largely close to zero (or average levels of each personality trait). This is likely due to a great deal of occupational heterogeneity remaining in the self-employed category. Individuals working in family enterprises or doing domestic work in other households have negative levels of conscientiousness, extroversion, openness to experience, and agreeableness. It is also the only category to exhibit positive levels of neuroticism.

\section{Tables}

Table 9.1 Standardized personality trait factor scores by gender

\begin{tabular}{|l|rr|rr|rr|r|}
\hline & \multicolumn{2}{|c|}{ Male } & \multicolumn{2}{c|}{ Female } & Total & Difference \\
\hline Conscientiousness & 811 & 0.061 & 881 & -0.048 & 1692 & 0.005 & 0.109 \\
Extroversion & 811 & 0.103 & 881 & -0.086 & 1692 & 0.005 & 0.189 \\
Neuroticism & 811 & -0.083 & 881 & 0.070 & 1692 & -0.003 & -0.152 \\
Openness to experience & 811 & 0.117 & 881 & -0.098 & 1692 & 0.005 & 0.215 \\
Agreeableness & 811 & 0.062 & 881 & -0.048 & 1692 & 0.005 & 0.110 \\
\hline
\end{tabular}

Table 9.2 Standardized personality trait factor by school enrollment status

\begin{tabular}{|l|rr|rr|rr|r|}
\hline & \multicolumn{2}{|c|}{ Currently in School } & \multicolumn{2}{c|}{ Currently Not in School } & \multicolumn{2}{c|}{ Total } & Difference \\
\hline Conscientiousness & 366 & 0.194 & 1326 & -0.053 & 1697 & 0.002 & 0.247 \\
Extroversion & 366 & 0.145 & 1326 & -0.037 & 1697 & 0.004 & 0.182 \\
Neuroticism & 366 & -0.025 & 1326 & 0.013 & 1697 & 0.007 & -0.039 \\
Openness to experience & 366 & 0.334 & 1326 & -0.084 & 1697 & 0.009 & 0.418 \\
Agreeableness & 366 & 0.104 & 1326 & -0.033 & 1697 & -0.001 & 0.136 \\
\hline
\end{tabular}


Table 9.3 Standardized personality traits by last school enrolled

\begin{tabular}{|c|c|c|c|c|c|c|c|c|c|c|c|c|}
\hline & \multicolumn{2}{|c|}{ Kindergarten } & \multicolumn{2}{|c|}{ Community } & \multicolumn{2}{|c|}{ Primary } & \multicolumn{2}{|c|}{ College/CEG } & \multicolumn{2}{|c|}{ High School } & \multicolumn{2}{|c|}{ University } \\
\hline & $\mathrm{N}$ & Mean & $\mathrm{N}$ & Mean & $\mathrm{N}$ & Mean & $\mathrm{N}$ & Mean & $\mathrm{N}$ & Mean & $\mathrm{N}$ & Mean \\
\hline Conscientiousness & 1 & -2.82 & 8 & -0.09 & 614 & -0.17 & 481 & -0.05 & 432 & 0.19 & 153 & 0.35 \\
\hline Extroversion & 1 & -1.79 & 8 & -0.41 & 614 & -0.19 & 481 & -0.02 & 432 & 0.21 & 153 & 0.33 \\
\hline Neuroticism & 1 & 1.42 & 8 & 0.84 & 614 & 0.09 & 481 & 0.06 & 432 & -0.12 & 153 & -0.21 \\
\hline Openness to experience & 1 & -1.74 & 8 & -0.37 & 614 & -0.27 & 481 & -0.02 & 432 & 0.25 & 153 & 0.51 \\
\hline Agreeableness & 1 & -1.78 & 8 & 0.40 & 614 & -0.13 & 481 & -0.01 & 432 & 0.14 & 153 & 0.15 \\
\hline
\end{tabular}

Table 9.4 Standardized personality traits by occupational xategory

\begin{tabular}{|c|c|c|c|c|c|c|c|c|c|c|c|c|c|c|c|}
\hline & \multicolumn{3}{|c|}{ Public/Private Sector } & \multicolumn{3}{|c|}{$\underline{\text { Self-Employed }}$} & \multicolumn{3}{|c|}{$\frac{\text { Famliy Enterprise/ }}{\text { Domestic Work }}$} & \multicolumn{3}{|c|}{$\underline{\text { Student }}$} & \multicolumn{3}{|c|}{ Unemployed } \\
\hline & $\mathrm{N}$ & Mean & $\begin{array}{l}\text { Standard } \\
\text { Deviation }\end{array}$ & $\mathrm{N}$ & Mean & $\begin{array}{l}\text { Standard } \\
\text { Deviation }\end{array}$ & $\mathrm{N}$ & Mean & $\begin{array}{l}\text { Standard } \\
\text { Deviation }\end{array}$ & $\mathrm{N}$ & Mean & $\begin{array}{l}\text { Standard } \\
\text { Deviation }\end{array}$ & $\mathrm{N}$ & Mean & $\begin{array}{l}\text { Standard } \\
\text { Deviation }\end{array}$ \\
\hline Conscientiousness & 207 & 0.25 & 0.89 & 412 & 0.06 & 0.92 & 656 & -0.18 & 1.04 & 257 & 0.18 & 0.92 & 105 & 0.17 & 1.18 \\
\hline Extroversion & 207 & 0.19 & 0.87 & 412 & 0.02 & 0.94 & 656 & -0.16 & 1.03 & 257 & 0.14 & 0.95 & 105 & 0.18 & 1.18 \\
\hline Neuroticism & 207 & -0.15 & 0.90 & 412 & -0.01 & 0.97 & 656 & 0.04 & 1.01 & 257 & -0.04 & 1.02 & 105 & -0.02 & 1.09 \\
\hline Openness to experience & 207 & 0.32 & 0.86 & 412 & -0.06 & 0.95 & 656 & -0.20 & 1.00 & 257 & 0.36 & 0.91 & 105 & 0.07 & 1.21 \\
\hline Agreeableness & 207 & 0.14 & 0.97 & 412 & 0.03 & 0.96 & 656 & -0.10 & 0.99 & 257 & 0.11 & 0.99 & 105 & 0.08 & 1.19 \\
\hline
\end{tabular}


Figures-Personality Traits

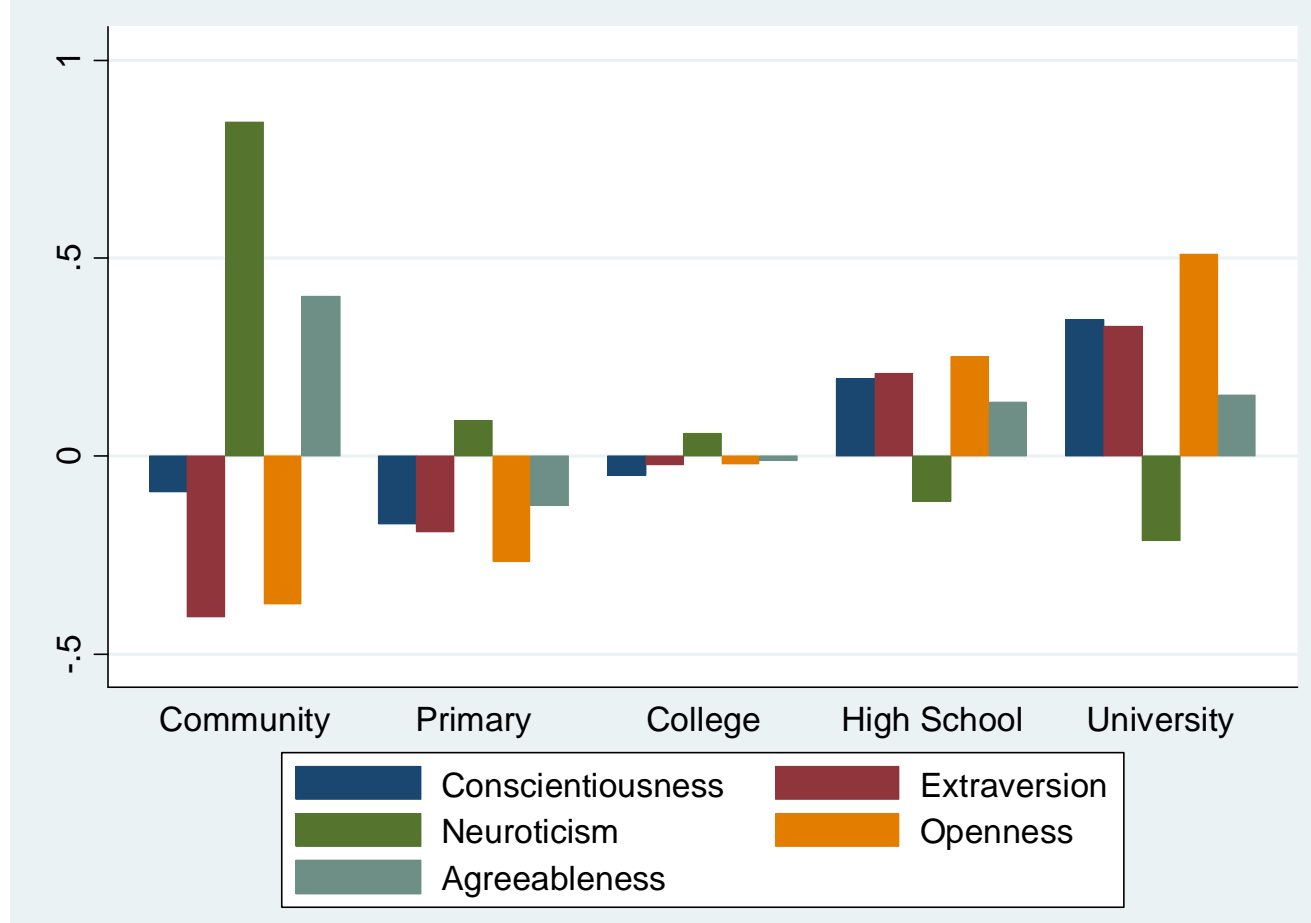

Fig. 9.1 Personality traits by last school enrolled

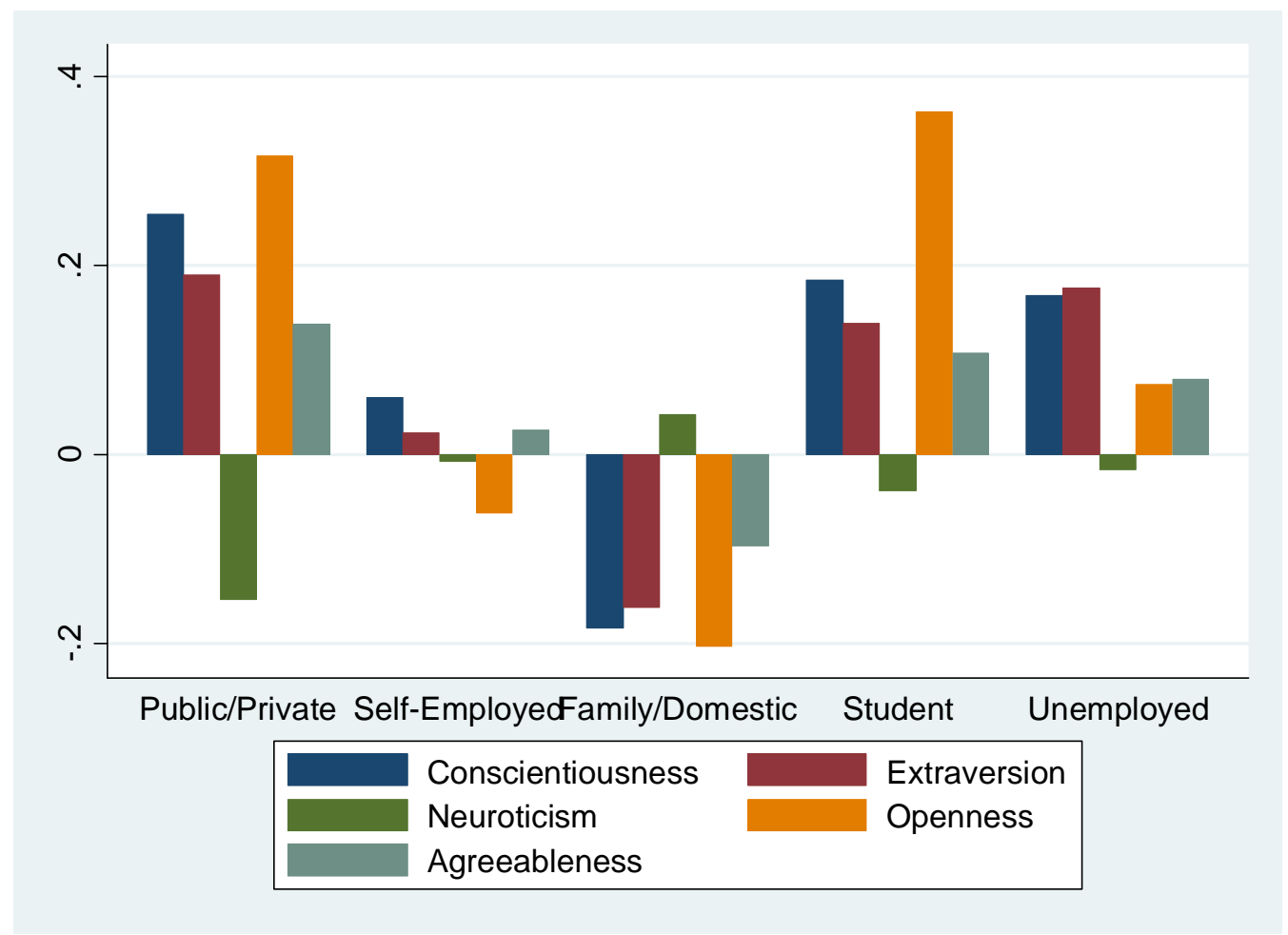

Fig. 9.2 Standardized personality traits by occupational category 


\section{Entrepreneurship}

Three-quarters of entrepreneurial activities performed were created from many small enterprises, and do not represent the resumption of any existing activity from parents or family. The main motivation is to supplement the family income. With little access to credit from formal institutions such as banks or microcredit, start-up funds consists mainly of personal contributions and support from the family. Two types of activities are identified: agriculture and livestock, on the one hand, and trade on the other hand. These are small businesses not hiring a lot of capital, with low turnover, and a small size (two or three workers on average). These enterprises are associated with certain characteristics of informality, such as non-registration with the appropriate authorities. Only six out of 250 pay taxes, and five are registered at INSTAT. This informality relates also to the lack of access to loans from banks or microfinance institutions. The complexity of application procedures and fears of inability to pay are so pervasive that most prefer to rely on support from the family. Moreover, only a small part of the profits is re-invested in the business. This greatly reduces the potential for expansion of these activities.

\section{Tables}

Table 10.1 Main reasons to undertake an activity

\begin{tabular}{|l|r|}
\hline & \multicolumn{1}{|c|}{ Percent } \\
\hline Family tradition & 11.82 \\
\hline To supplement the family income & 41.13 \\
\hline To have a higher income than from wage employment & 6.16 \\
\hline To have a flexible work schedule and be one's own boss & 5.17 \\
\hline Desire for independence & 18.97 \\
\hline Loss of previous job & 0.49 \\
\hline This is a good business opportunity & 4.68 \\
\hline Could not find another job & 11.58 \\
\hline & 100.00 \\
\hline
\end{tabular}


Table 10.2 Sources of funding at the activity start-up

\begin{tabular}{|l|r|}
\hline & \multicolumn{1}{|c|}{ Percent } \\
\hline Borrowing from family members without interest & 12.56 \\
\hline Borrowing from family members with interest & 2.42 \\
\hline Borrowing from friends without interest & 3.86 \\
\hline Transfers from abroad & 0.48 \\
\hline Private lenders & 3.86 \\
\hline Own savings & 40.58 \\
\hline Bank loans & 1.93 \\
\hline Loans from microcredit institutions & 0.97 \\
\hline Sale of family goods & 1.93 \\
\hline Credit from suppliers & 0.97 \\
\hline Inheritance from a parent or other family member & 6.28 \\
\hline Donations from parents, family members, or friends & 14.98 \\
\hline Liquidation from previous job & 0.48 \\
\hline Other & 8.70 \\
\hline Total & 100.00 \\
\hline
\end{tabular}

Table 10.3 Distribution of businesses by use of profits

\begin{tabular}{|c|c|c|c|}
\hline Use & $\begin{array}{l}\frac{\text { Re-invested }}{\text { in the }} \\
\text { business }\end{array}$ & $\begin{array}{c}\frac{\text { For the use of }}{\begin{array}{c}\text { one's } \\
\text { household } \\
\text { needs }\end{array}} \\
\end{array}$ & $\frac{\text { For the use of }}{\frac{\text { one's own }}{\text { needs }}}$ \\
\hline $\mathrm{N}$ & 251 & 243 & 247 \\
\hline Part & Percent & Percent & Percent \\
\hline All or almost all & 3.29 & 26.72 & 3.78 \\
\hline More than half & 19.75 & 29.96 & 4.62 \\
\hline Nearly half & 13.58 & 17.41 & 5.04 \\
\hline Less than half & 10.29 & 12.15 & 11.76 \\
\hline Quarter or less & 13.17 & 8.50 & 30.25 \\
\hline \multirow[t]{2}{*}{ No part } & 39.92 & 5.26 & 44.54 \\
\hline & 100.00 & 100.00 & 100.00 \\
\hline
\end{tabular}


Table 10.4 Main reasons not to ask for a loan from a bank or microfinance institution

\begin{tabular}{|l|r|}
\hline \multicolumn{1}{|c|}{ Reason } & Percent \\
\hline $\begin{array}{l}\text { I did not think that banks lend to people } \\
\text { like me. }\end{array}$ & 23.89 \\
\hline High interest rates & 9.22 \\
\hline I have no collateral & 10.48 \\
\hline I feel no need to borrow & 22.43 \\
\hline I am suspicious about loans & 8.39 \\
\hline $\begin{array}{l}\text { Problems of eligibility other than } \\
\text { collateral }\end{array}$ & 5.24 \\
\hline Concerns about paying back loan & 12.37 \\
\hline Other reasons & 7.98 \\
\hline Total & 100.00 \\
\hline
\end{tabular}

\section{Agriculture}

Concerning more than $75 \%$ of labor force, agriculture issues are very important for Madagascar, and particularly for young people. Taking into account the cultural value of land and conditions of life in rural areas, the probability of intergenerational transfer of agricultural professions is relatively high and access to other activities is difficult. Most of young people are family workers, the access to independent status is late and difficult because of respect for parents, risk aversion, and non-availability of agricultural and rural insurance systems. Finally, the premature entry of children and teenagers into the agricultural labor market influences their schooling, and thus, their life course.

The survey allows us to analyze the conditions of activities on farms for young members of the cohort households: access to land and machinery, farm area, land and livestock acquisition mode, and capital value. We make the analysis for two different groups of households. The first group contains all the "original households" in which cohort members belonged and which did not change since the last survey in 2003. The second group is composed of "new households" in which cohort members belong now and which are different from their households in 2003. A large majority of these new household are created by the young cohort members themselves after separation with their original households (marriage, migration). By analysis of the situation in the two groups of households, we can determine the evolution of agricultural activities for young persons in terms of capital accumulation.

For the survey, farms were considered "possessed" whether on owned or rented lands, or given to the household by another entity (government, company, other households). Six categories of lands were considered: rice fields, lands for cash-culture, lands for fruit trees-forest-orchards, lands for root and tuber crops, and lands for other crops.

The results show that, among the households of young cohort members, more than $71.4 \%$ possess farms. Rice farming is the most practiced, which is engaged in by $62.7 \%$ of households in Madagascar. This is consistent with the fact that rice is the staple food for the Malagasy people in all 
regions. Then, root and tuber crops account for the second largest production with about $54.7 \%$ occupied households. The cash crops and fruit trees planting are relatively rare.

According to the two different groups of households, the practice of the agriculture is less frequent for the "new households" of cohort members. Less than $61.2 \%$ of them farm lands, whereas the percentage is more than $81.4 \%$ for the "original households." This result is valid for each category of lands. So, two interpretations are possible. On the one hand, the cohort of young people move more frequently to non-agricultural households, confirming the phenomenon of the rural exodus. Despite this phenomenon, the transfer of agricultural activities between generations remains important. On the other hand, the separation of the young people from their original household is earlier in non-agricultural households than in agricultural households. (Table 11.1).

In Madagascar, agriculture is still dominated by subsistence activities and small-scale farms. The average area is estimated about 94.1 hectares per household. With an average household size about 4.9 persons in rural areas, the large majority of agricultural households are suffering financial hardship and often fall into a poverty trap: low level of production capacity, low income, low rate of capital accumulation, low farm yields. Young people have to face these precarious living conditions for which they were not directly responsible.

The survey also revealed strong inequalities in land distribution between agricultural households. If the median area is only 13.0 ares per agricultural household, $10 \%$ among them farm, on average, more than two hectares. These figures are consistent with the findings of 2011-2012 household survey. There might be a number of reasons for this, e.g., the slow development of land market, differences in weather conditions and relief between regions, initial land endowments, and inefficiency of public lands reallocation policies.

Even if rice growing is the most practiced, it is less important in terms of planted area surface with only 37.6 ares per household. The average farm sizes for other crops are significantly larger: 62.8 ares per household for fruit tree forest-orchard lands, 53.4 ares per household for lands for cash crops, and 48.5 ares per household for lands for root and tuber crops. Traditional rice growing techniques, mainly adopted by agricultural households, are practiced only in small areas: on lowland, irrigated rice fields or the slopes of mountains. The upland rice farming, large scale irrigated surfaces, and mechanized rainfed farming are especially operated by big societies.

The removal of a young person from one household to another is often accompanied by a slight improvement in that young person's situation, with respect to farm size. Indeed, the average area utilized by the "new households" is significantly more important compared with those of the "original households": 99.4 ares vs. 88.9 ares. This finding is valid for all land categories except lands for fruit tree forest-orchards : 69.8 ares vs. 41.5 ares for lands for cash crops, 50.6 ares vs. 46.5 ares for lands for root and tuber crops, and 42.4 ares vs. 32.8 ares for rice fields. One the other hand, for fruit trees forest-orchards lands, the average area for "new households" is slightly less than for "original households": 56.7 ares vs. 67.1 ares (Table 11.2).

In addition to access to land mentioned previously, the climate and watering system represent major constraints which reduce lands yields, lead to suboptimum use of lands, and limit productive capacity in agriculture. As Madagascar is a big island and little continent, various agroclimatic zones can be found: semi-desert plateau with hot and dry climate in the south, large plain with moderate continental climate in the west, mountainous areas with wet climate in the east, fertile uplands and lowlands with temperate climate in the center, and finally, plains with wet climate in the North. Because of water control problems and agricultural habits, monoculture prevails, and off-season crops (dry season) are practiced only in Madagascar's central highlands. 
According to the results of the survey, more than $52 \%$ of the lands farmed by the households are cultivable only during the rainy period. Obviously, it depends on the type of crops. The riceproduction is feasible only during the rainy period for more than $38 \%$ of the available lands. For root and tuber crops, the case appears for $28.6 \%$ of lands. For other types of culture, the constraint is less important: the culture is possible even during dry period except for $7.7 \%$ of of the cash-crops lands, $6.4 \%$ for fruit tree forest-orchard lands, and $2.2 \%$ for other types of crops.

For young cohort members who changed agricultural households between 2003-2011, the situation is substantially better: a larger part of the farmed lands were cultivable during dry period. For the "new households," more than $54.3 \%$ of lands were cultivable during dry periods, whereas for the "original households," this proportion is only $40 \%$ (Table 11.3).

The unequal and inefficient distribution of land is the most important cause of vulnerability for agricultural households. More than $82.3 \%$ of agricultural households are individually landowners. In $11.9 \%$ of the cases, lands do not belong to the farming household. Jointly-owned land is relatively rare: less than $6 \%$ of the total. These proportions vary according to the category of lands. More than $89.5 \%$ of lands for fruit tree forests-orchard crops and $87.9 \%$ of cash crop lands are individually owned by the households. This proportion decreases to $79.3 \%$ for rice fields. The "new households" of young cohort members are less frequently landowners: only $77.1 \%$ vs. more than $87.2 \%$ for "original households."We find the same result for each category of lands (Table 11.4).

More than $72.7 \%$ of lands owned by households were acquired by inheritance. Purchased farms constitute only $17.6 \%$ of the land acquisitions. Other acquisition modes like clearing or donations (family or friend, local state, State) are relatively rare. Concerning cash crop lands, the inheritance is less frequently: only $67 \%$ of lands are transferred in this manner. The endowments of lands of the "new households" " of young cohort members are much more likely to be transmitted by inheritance: $78.2 \%$ of the cases vs. only $68.2 \%$ for "original households" (Table 11.5).

The average value of the land endowments is estimated at 3,721,300 Ariary per household. According to the category of lands, the average values are different: 2,712,700 Ariary for rice fields, $1,422,600$ Ariary of cash-crop lands, 1,178,800 Ariary of lands for fruit tree forest-orchards, $1,020,100$ Ariary of lands for root and tuber crops. "New households" are less provided with less land value by more than half as compared to the "original households: 2,455,000 Ariary vs. 4,861,000 Ariary (Table 11.6).

The outcomes confirm strong support of Malagasy households for the social and cultural value of lands. The land transfers are rare and have an exceptional character to the households. Only 65 households, among 1,555 households, of young cohort members (or 4.2\%) sold, gave, or abandoned the lands that they operated during the last 10 years. Especially for "new households," the proportion is much lower: only 7 households, among 851 households. More than half of surrendered lands are rice fields and a third part are lands for root and tuber crops. The land market is still weakly developed in Madagascar. Less than $58.7 \%$ of surrendered lands were sold. The donations to families or friends accounted for more than $38 \%$ of the cases. Expropriation is nearly non-existent (Table 11.7).

The agricultural production remains technologically backward, which leads to slow progress in productivity, profitability improvement and rural welfare in Madagascar. The agricultural mechanization is still at the embryonic state, and access to machinery is limited. Just over two-thirds of agricultural households possess farm equipment. Furthermore, these materials are in most cases small equipment such as mowers and pestles: $56.4 \%$ and $50.9 \%$, respectively, of households possess 
these two pieces of equipment. On the other hand, even for the essential agricultural materials such as plow, harrow, and weeder, less than $16 \%$ of the households have access to these implements.

Concerning the big machines and more sophisticated equipment as tractors, watering systems, threshing machines, and peeling machines, most of the agricultural households are deprived. The situation is not the same between the "new households" and the "original households" of young cohort members: those in the latter category are much more supplied-more than $77 \%$ of households possess farm implements, and the difference is valid even for the small equipment.

The evaluation of farm equipment gives an estimation of physical capital amount: on average, about 119,700 Ariary per agricultural household. The disparity is very strong because half of them possess only approximately 30,000 Ariary (median). For the "new households," the value is twice as low as compared with that of the "original households" (Table 11.8).

Concerning the farm animals, about $63 \%$ of households own livestock. The small farm animals, particularly, laying hens, are the most frequent. More than half the households $(51 \%)$ of the young cohort members have these. Cattle and pig farming concern $17 \%$ and $16 \%$, respectively, of households. On the other hand, only $2 \%$ of households are dairy cow farmers. "New households" of young cohort member are also have less livestock: $55 \%$ of them possess livestock. This percentage exceeds $77 \%$ for "original households." This difference remains valid for any type of animal breeding (Table 11.9).

More than $63 \%$ of farmers acquired their livestock by purchases. About $30 \%$ of livestock are new animal offspring bred by the farmers from existing livestock. Transfers such as inheritance, gifts, and dowries account for only $10 \%$ of the acquisitions. These latter modes of livestock are employed more frequently by the "new households" of young cohort members, representing more than $14 \%$ of these households' acquisitions. They are still at the beginning of the process of capital accumulation.

The average value of livestock is estimated to 2,503,000 Ariary per household: 1,928,000 Ariary for "new households" and more than 3,055,000 Ariary for "original households." For the households possessing zebus or oxen, the average values per farmer are 2,655,000 Ariary and $4,397,000$ Ariary, respectively; for the pork farmer, the values are more than 413,000 Ariary and less than 92,000 Ariary for chicken (laying hens) farmer.

Tables

Table 11.1 Proportion of agricultural households (\%)

\begin{tabular}{|c|c|c|c|c|c|c|}
\hline$\frac{\text { Household }}{\text { type }}$ & $\begin{array}{c}\frac{\text { All }}{\text { categories }} \\
\text { of land }\end{array}$ & $\underline{\text { Rice fields }}$ & $\frac{\text { Land for cash }}{\underline{\text { crop }}}$ & $\frac{\text { Land for fruit trees, }}{\underline{\text { forest }}}$ & $\begin{array}{l}\text { Land for root } \\
\text { and tuber crop }\end{array}$ & $\begin{array}{l}\text { Land for } \\
\text { other crops }\end{array}$ \\
\hline Original HH & 81.49 & 69.87 & 17.79 & 17.07 & 62.98 & 3.73 \\
\hline New HH & 63.17 & 56.99 & 10.61 & 9.44 & 48.02 & 2.80 \\
\hline Total & 71.38 & 62.77 & 13.83 & 12.86 & 54.73 & 3.22 \\
\hline
\end{tabular}


Table 11.2 Average area of operated lands (ares per household)

\begin{tabular}{|l|c|c|c|c|c|c|}
\hline \multicolumn{1}{|c|}{$\begin{array}{c}\text { Household } \\
\text { type }\end{array}$} & $\begin{array}{c}\text { All } \\
\text { categories } \\
\text { of land }\end{array}$ & Rice fields & $\frac{\text { Land for cash }}{\text { crop }}$ & $\frac{\text { Land for fruit trees, }}{\text { forest }}$ & $\begin{array}{c}\text { Land for root } \\
\text { and tuber crop }\end{array}$ & $\begin{array}{c}\text { Land for } \\
\text { other crops }\end{array}$ \\
\hline Original HH & 89.0 & 32.8 & 41.5 & 67.1 & 46.5 & 47.2 \\
New HH & 99.4 & 42.4 & 69.8 & 56.7 & 50.6 & 61.0 \\
Total & 94.1 & 37.6 & 53.5 & 62.8 & 48.5 & 53.8 \\
\hline
\end{tabular}

Table 11.3 Proportion of lands operated only during rainy period (\%)

\begin{tabular}{|l|c|c|c|c|c|c|}
\hline \multicolumn{1}{|c|}{$\begin{array}{c}\text { Household } \\
\text { type }\end{array}$} & $\begin{array}{c}\text { All } \\
\text { categories } \\
\text { of land }\end{array}$ & Rice fields & $\frac{\text { Land for cash }}{\text { crop }}$ & $\frac{\text { Land for fruit trees, }}{\text { forest }}$ & $\begin{array}{c}\text { Land for root } \\
\text { and tuber crop }\end{array}$ & $\begin{array}{c}\underline{\text { Land for }} \\
\text { other crops }\end{array}$ \\
\hline Original HH & 60.11 & 43.04 & 8.90 & 8.61 & 31.28 & 2.44 \\
New HH & 45.69 & 34.15 & 6.76 & 4.66 & 26.46 & 2.10 \\
Total & 52.15 & 38.14 & 7.72 & 6.43 & 28.62 & 2.25 \\
\hline
\end{tabular}

Table 11.4a Part of land for rice crop owned by operated household (\%)

\begin{tabular}{|c|c|c|c|c|c|c|}
\hline$\frac{\text { Household }}{\text { type }}$ & Totality & $\begin{array}{l}\text { Large } \\
\text { parts } \\
\end{array}$ & $\begin{array}{l}\text { Just more } \\
\text { than half }\end{array}$ & Less than half & Without part & Total \\
\hline Original & & & & & & \\
\hline $\mathrm{HH}$ & 85.22 & 3.90 & 2.05 & 0.62 & 8.21 & 100.00 \\
\hline New HH & 73.42 & 3.89 & 2.86 & 1.64 & 18.20 & 100.00 \\
\hline Total & 79.30 & 3.89 & 2.46 & 1.13 & 13.22 & 100.00 \\
\hline
\end{tabular}

Table 11.4b Part of land for cash crop owned by operated household (\%)

\begin{tabular}{|c|c|c|c|c|c|c|}
\hline$\frac{\text { Household }}{\text { type }}$ & Totality & $\begin{array}{l}\text { Large } \\
\text { parts } \\
\end{array}$ & $\begin{array}{l}\text { Just more } \\
\text { than half }\end{array}$ & Less than half & Without part & Total \\
\hline Original & & & & & & \\
\hline $\mathrm{HH}$ & 91.94 & 4.03 & 0.00 & 0.00 & 4.03 & 100.00 \\
\hline New HH & 82.42 & 3.30 & 1.10 & 0.00 & 13.19 & 100.00 \\
\hline Total & 87.91 & 3.72 & 0.47 & 0.00 & 7.91 & 100.00 \\
\hline
\end{tabular}

Table 11.4c Part of land for fruit trees, forest owned by operated household (\%)

\begin{tabular}{|c|c|c|c|c|c|c|}
\hline $\begin{array}{c}\frac{\text { Household }}{\text { type }} \\
\end{array}$ & Totality & $\begin{array}{l}\text { Large } \\
\text { parts } \\
\end{array}$ & $\begin{array}{l}\text { Just more } \\
\text { than half }\end{array}$ & Less than half & Without part & $\underline{\text { Total }}$ \\
\hline Original & & & & & & \\
\hline $\mathrm{HH}$ & 92.44 & 2.52 & 0.84 & 0.00 & 4.20 & 100.00 \\
\hline New HH & 85.19 & 2.47 & 2.47 & 1.23 & 8.64 & 100.00 \\
\hline Total & 89.50 & 2.50 & 1.50 & 0.50 & 6.00 & 100.00 \\
\hline
\end{tabular}


Table 11.4d Part of land for root and tuber crop owned by operated household (\%)

\begin{tabular}{|l|c|c|c|c|c|c|}
\hline $\begin{array}{l}\text { Household } \\
\text { type }\end{array}$ & $\underline{\text { Totality }}$ & $\begin{array}{c}\underline{\text { Large }} \\
\text { parts }\end{array}$ & $\begin{array}{c}\text { Just more } \\
\text { than half }\end{array}$ & $\underline{\text { Less than half }}$ & Without part & $\underline{\text { Total }}$ \\
\hline Original & & & & & & \\
HH & 86.79 & 3.87 & 0.46 & 0.46 & 8.43 & 100.00 \\
New HH & 79.85 & 2.91 & 0.97 & 0.49 & 15.78 & 100.00 \\
Total & 83.43 & 3.41 & 0.71 & 0.47 & 11.99 & 100.00 \\
\hline
\end{tabular}

Table 11.4e Part of land for other crop owned by operated household (\%)

\begin{tabular}{|c|c|c|c|c|c|c|}
\hline$\frac{\text { Household }}{\text { type }}$ & Totality & $\begin{array}{l}\text { Large } \\
\text { parts }\end{array}$ & $\frac{\text { Just more }}{\text { than half }}$ & Less than half & Without part & Total \\
\hline $\begin{array}{l}\text { Original } \\
\mathrm{HH}\end{array}$ & 84.62 & 0.00 & 0.00 & 0.00 & 15.38 & 100.00 \\
\hline New $\mathrm{HH}$ & 58.33 & 0.00 & 0.00 & 0.00 & 41.67 & 100.00 \\
\hline Total & 72.00 & 0.00 & 0.00 & 0.00 & 28.00 & 100.00 \\
\hline
\end{tabular}

Table 11.4 Part of land (all categories) owned by operated household (\%)

\begin{tabular}{|c|c|c|c|c|c|c|}
\hline$\frac{\text { Household }}{\text { type }}$ & Totality & $\begin{array}{l}\text { Large } \\
\text { parts } \\
\end{array}$ & $\begin{array}{l}\text { Just more } \\
\text { than half }\end{array}$ & Less than half & $\underline{\text { Without part }}$ & Total \\
\hline $\begin{array}{l}\text { Original } \\
\mathrm{HH}\end{array}$ & 87.22 & 3.68 & 1.09 & 0.42 & 7.60 & 100.00 \\
\hline New HH & 77.12 & 3.28 & 1.91 & 1.00 & 16.68 & 100.00 \\
\hline Total & 82.39 & 3.49 & 1.48 & 0.70 & 11.94 & 100.00 \\
\hline
\end{tabular}

Table 11.5a Lands acquisition modes : land for rice crop (\%)

\begin{tabular}{|l|c|c|c|c|c|c|}
\hline $\begin{array}{l}\text { Household } \\
\text { type }\end{array}$ & Inheritance & Clearing & Purchase & $\frac{\text { Donation from local }}{\text { authority }}$ & $\frac{\text { Donation from }}{\text { State }}$ & $\underline{\underline{\text { Friends, }}}$ \\
\hline Original & & & & & & \\
HH & 71.90 & 2.21 & 22.79 & 0.44 & 1.11 & 0.88 \\
New HH & 78.04 & 1.91 & 10.98 & 0.48 & 0.24 & 3.82 \\
Total & 74.86 & 2.07 & 17.11 & 0.46 & 0.69 & 2.30 \\
\hline
\end{tabular}

Table 11.5b Lands acquisition modes : land for cash crop (\%)

\begin{tabular}{|l|c|c|c|c|c|c|}
\hline $\begin{array}{l}\text { Household } \\
\text { type }\end{array}$ & Inheritance & Clearing & Purchase & $\frac{\text { Donation from local }}{\text { authority }}$ & $\frac{\text { Donation from }}{\text { State }}$ & $\underline{\underline{\text { Friends, }}}$ \\
\hline Original & & & & & & \\
HH & 61.67 & 7.50 & 25.00 & 2.50 & 0.83 & 0.83 \\
New HH & 73.75 & 5.00 & 16.25 & 2.50 & 0.00 & 1.25 \\
Total & 66.50 & 6.50 & 21.50 & 2.50 & 0.50 & 1.00 \\
\hline
\end{tabular}


Table 11.5c Lands acquisition modes : land for fruit trees, forest (\%)

\begin{tabular}{|l|c|c|c|c|c|c|}
\hline $\begin{array}{l}\text { Household } \\
\text { type }\end{array}$ & Inheritance & Clearing & Purchase & $\frac{\text { Donation from local }}{\text { authority }}$ & $\underline{\text { Donation from }}$ & $\underline{\underline{\text { Friends, }}}$ \\
\hline Original & & & & & $\underline{\text { family }}$ \\
HH & 65.22 & 5.22 & 24.35 & 0.87 & 2.61 & 0.00 \\
New HH & 75.68 & 10.81 & 9.46 & 1.35 & 0.00 & 0.00 \\
Total & 69.31 & 7.41 & 18.52 & 1.06 & 1.59 & 0.00 \\
\hline
\end{tabular}

Table 11.5d Lands acquisition modes : land for root and tuber crop (\%)

\begin{tabular}{|l|c|c|c|c|c|c|}
\hline $\begin{array}{l}\text { Household } \\
\text { type }\end{array}$ & Inheritance & Clearing & Purchase & $\frac{\text { Donation from local }}{\text { authority }}$ & $\frac{\text { Donation from }}{\text { State }}$ & $\underline{\underline{\text { Friends, }}}$ \\
\hline Original & & & & & & \\
HH & 67.00 & 5.17 & 22.66 & 0.99 & 1.23 & 2.22 \\
New HH & 78.93 & 2.53 & 10.96 & 0.56 & 1.40 & 3.65 \\
Total & 72.57 & 3.94 & 17.19 & 0.79 & 1.31 & 2.89 \\
\hline
\end{tabular}

Table 11.5e Lands acquisition modes : land for other crops (\%)

\begin{tabular}{|l|c|c|c|c|c|c|}
\hline $\begin{array}{l}\text { Household } \\
\text { type }\end{array}$ & Inheritance & Clearing & Purchase & $\frac{\text { Donation from local }}{\text { authority }}$ & $\frac{\text { Donation from }}{\text { State }}$ & $\underline{\underline{\text { Friends, }}}$ \\
\hline Original & & & & & & \\
HH & 69.57 & 4.35 & 17.39 & 4.35 & 0.00 & 4.35 \\
New HH & 100.00 & 0.00 & 0.00 & 0.00 & 0.00 & 0.00 \\
Total & 81.58 & 2.63 & 10.53 & 2.63 & 0.00 & 2.63 \\
\hline
\end{tabular}

Table 11.5 Lands acquisition modes : all categories of land (\%)

\begin{tabular}{|l|c|c|c|c|c|c|}
\hline $\begin{array}{l}\text { Household } \\
\text { type }\end{array}$ & Inheritance & Clearing & Purchase & $\frac{\text { Donation from local }}{\text { authority }}$ & $\frac{\text { Donation from }}{\text { State }}$ & $\underline{\underline{\text { Friends, }}}$ \\
\hline Original & & & & & & \\
HH & 68.16 & 4.20 & 23.17 & 0.98 & 1.25 & 1.34 \\
New HH & 78.18 & 3.07 & 11.12 & 0.74 & 0.64 & 3.18 \\
Total & 72.74 & 3.69 & 17.65 & 0.87 & 0.97 & 2.18 \\
\hline
\end{tabular}

Table 11.6 Average amount of operated lands (1,000 Ariary)

\begin{tabular}{|c|c|c|c|c|c|c|}
\hline$\frac{\text { Household }}{\text { type }}$ & $\begin{array}{c}\text { All categories } \\
\text { of land }\end{array}$ & Rice fields & $\begin{array}{l}\frac{\text { Land for cash }}{\text { crop }} \\
\end{array}$ & $\begin{array}{c}\text { Land for fruit trees, } \\
\text { forest }\end{array}$ & $\begin{array}{l}\text { Land for root } \\
\text { and tuber crop }\end{array}$ & $\begin{array}{l}\text { land for } \\
\text { other crops }\end{array}$ \\
\hline Original & & & & & & \\
\hline $\mathrm{HH}$ & $4,861.18$ & $3,584.02$ & $1,840.13$ & $1,463.02$ & $1,226.34$ & $1,075.20$ \\
\hline New HH & $2,455.73$ & $1,773.34$ & 818.93 & 733.42 & 787.00 & 346.07 \\
\hline Total & $3,721.25$ & $2,712.75$ & $1,422.60$ & $1,178.86$ & $1,020.13$ & 801.77 \\
\hline
\end{tabular}

Note: Earnings are reported in Ariary. 1,000 Ariary is 0.45 US\$ (7 November 2013) 
Table 11.7 Proportion of agricultural households having given up lands (\%)

\begin{tabular}{|l|r|r|r|}
\hline \multicolumn{1}{|c|}{ Household } & Not given up & Given up land & \multicolumn{2}{|l|}{ Total } \\
\hline Original & land & & \\
HH & 639 & 58 & 697 \\
New HH & 851 & 7 & 858 \\
Total & 1,490 & 65 & 1,555 \\
\hline
\end{tabular}

Table 11.7a Category of land transferred (\%)

\begin{tabular}{|c|c|c|c|c|c|c|}
\hline$\frac{\text { Household }}{\text { type }}$ & $\begin{array}{c}\text { All } \\
\frac{\text { categories }}{\text { of land }}\end{array}$ & $\underline{\text { Rice fields }}$ & $\begin{array}{l}\text { Land for cash } \\
\text { crop }\end{array}$ & $\begin{array}{l}\text { land for fruit } \\
\underline{\text { trees, forest }}\end{array}$ & $\begin{array}{l}\text { Land for } \\
\text { root and } \\
\text { tuber crop }\end{array}$ & $\begin{array}{l}\text { Land for } \\
\text { other crops }\end{array}$ \\
\hline Original HH & 55.38 & 7.69 & 0.00 & 29.23 & 7.69 & 100.00 \\
\hline New HH & 37.50 & 0.00 & 0.00 & 50.00 & 12.50 & 100.00 \\
\hline Total & 53.42 & 6.85 & 0.00 & 31.51 & 8.22 & 100.00 \\
\hline
\end{tabular}

Table 11.7b Proportion of landowners' households of land transferred (\%)

\begin{tabular}{|l|c|c|c|}
\hline $\begin{array}{l}\text { Household } \\
\text { type }\end{array}$ & landowners & $\begin{array}{c}\underline{\text { Not }} \\
\text { landowners }\end{array}$ & $\underline{\text { Total }}$ \\
\hline Original & 90.77 & 9.23 & 100.00 \\
HH & 50.00 & 50.00 & 100.00 \\
New HH & 86.30 & 13.70 & 100.00 \\
Total & \\
\hline
\end{tabular}

Table 11.7c Given up mode (\%)

\begin{tabular}{|l|c|c|c|c|c|}
\hline $\begin{array}{l}\text { Household } \\
\text { type }\end{array}$ & $\begin{array}{c}\text { Given to family } \\
\text { or friends }\end{array}$ & Sold & $\begin{array}{c}\frac{\text { Expropriation }}{\underline{\text { by local }}} \\
\text { authority }\end{array}$ & Flooding & Total \\
\hline Original & 37.29 & 59.32 & 1.69 & 1.69 & 100.00 \\
HH & 50.00 & 50.00 & 0.00 & 0.00 & 100.00 \\
New HH & 38.10 & 58.73 & 1.59 & 1.59 & 100.00 \\
Total & &
\end{tabular}

Table $11.7 d$ Given up motivation (\%)

\begin{tabular}{|c|c|c|c|c|c|c|}
\hline$\frac{\text { Household }}{\underline{\text { type }}}$ & Need money & $\frac{\text { Household }}{\text { problems }}$ & $\begin{array}{c}\text { Already have } \\
\text { enough parcels }\end{array}$ & $\begin{array}{l}\text { To help the } \\
\text { beneficiary } \\
\text { household }\end{array}$ & $\begin{array}{c}\text { Other } \\
\text { motivations }\end{array}$ & Total \\
\hline $\begin{array}{l}\text { Original } \\
\mathrm{HH}\end{array}$ & 63.16 & 5.26 & 0.00 & 24.56 & 7.02 & 100.00 \\
\hline New HH & 75.00 & 0.00 & 25.00 & 0.00 & 0.00 & 100.00 \\
\hline Total & 63.93 & 4.92 & 1.64 & 22.95 & 6.56 & 100.00 \\
\hline
\end{tabular}


Table 11.8 Proportion of households possessing agricultural equipments (\%)

\begin{tabular}{|c|c|c|c|c|c|c|c|c|c|c|c|c|c|c|}
\hline$\frac{\text { Household }}{\text { type }}$ & All types & $\underline{\text { Tractor }}$ & Plow & Harrow & $\frac{\text { Other traction }}{\text { materials }}$ & Cart & Vaporizer & Rake & $\begin{array}{l}\text { Watering } \\
\text { system }\end{array}$ & $\begin{array}{l}\text { Threshing } \\
\text { machine }\end{array}$ & $\begin{array}{l}\text { Decorti- } \\
\text { querie }\end{array}$ & Pestle & Jerry can & Reaper \\
\hline Original $\mathrm{HH}$ & 77.47 & 0.43 & 23.39 & 20.66 & 7.32 & 12.77 & 2.01 & 14.92 & 4.59 & 1.00 & 0.57 & 63.13 & 29.99 & 64.28 \\
\hline New HH & 59.21 & 0.00 & 11.31 & 12.35 & 5.59 & 5.48 & 0.82 & 6.41 & 2.45 & 0.35 & 0.12 & 41.03 & 21.68 & 50.00 \\
\hline Total & 67.40 & 0.19 & 16.72 & 16.08 & 6.37 & 8.75 & 1.35 & 10.23 & 3.41 & 0.64 & 0.32 & 50.93 & 25.40 & 56.40 \\
\hline
\end{tabular}

Table 11.8a Average amount of agricultural equipments (1,000 Ariary)

\begin{tabular}{|l|c|c|}
\hline Household type & Mean & Median \\
\hline Original HH & 150.50 & 37.00 \\
New HH & 87.21 & 25.00 \\
Total & 119.76 & 30.00 \\
\hline
\end{tabular}

Note: Earnings are reported in Ariary. 1,000 Ariary is 0.45 US\$ (7 November 2013)

Table 11.9 Proportion of households possessing livestock (\%)

\begin{tabular}{|c|c|c|c|c|c|c|c|c|c|c|}
\hline$\frac{\text { Household }}{\text { type }}$ & All categories & $\underline{\text { Zebu }}$ & Oxen & Cow & Pig & Sheep & Goat & Chickens & Duck & Other \\
\hline Original HH & 71.88 & 23.82 & 24.25 & 3.44 & 19.37 & 3.01 & 4.16 & 59.25 & 22.24 & 1.43 \\
\hline New HH & 55.94 & 11.77 & 15.73 & 0.93 & 14.10 & 2.45 & 4.20 & 45.10 & 15.38 & 0.58 \\
\hline Total & 63.09 & 17.17 & 19.55 & 2.06 & 16.46 & 2.70 & 4.18 & 51.45 & 18.46 & 0.96 \\
\hline
\end{tabular}


Table 11.9a Average amount of livestock (1,000 Ariary)

\begin{tabular}{|c|c|c|c|c|c|c|c|c|c|c|}
\hline$\frac{\text { Household }}{\text { type }}$ & All categories & Zebu & Oxen & Cow & Pig & Sheep & Goat & Chickens & Duck & Other \\
\hline Original HH & $3,055.12$ & $2,455.48$ & $5,029.85$ & $1,657.50$ & 457.72 & 535.24 & $2,926.34$ & 109.44 & 165.22 & 447.30 \\
\hline New HH & $1,928.15$ & $2,982.87$ & $3,604.74$ & 937.50 & 364.33 & 426.67 & 699.89 & 74.42 & 173.35 & 36.00 \\
\hline Total & $2,503.70$ & $2,654.98$ & 4,396.99 & $1,477.50$ & 413.58 & 480.95 & $1,693.23$ & 92.50 & 168.96 & 310.20 \\
\hline
\end{tabular}

Note: Earnings are reported in Ariary. 1,000 Ariary is 0.45 US\$ (7 November 2013) 
Table 11.9b Acquisition mode of livestock (\%)

\begin{tabular}{|l|c|c|c|c|c|c|c|}
\hline $\begin{array}{c}\text { Household } \\
\text { type }\end{array}$ & $\underline{\text { Inheritance }}$ & $\underline{\text { Gift }}$ & $\underline{\text { Dowry }}$ & $\underline{\text { Purchase }}$ & $\underline{\text { Farming }}$ & $\underline{\underline{\text { Other }}}$ & $\underline{\text { Total }}$ \\
\hline Original HH & 5.16 & 1.34 & 0.53 & 58.86 & 33.84 & 0.27 & 100.00 \\
New HH & 9.20 & 4.02 & 1.16 & 62.37 & 23.04 & 0.21 & 100.00 \\
Total & 7.01 & 2.56 & 0.82 & 60.46 & 28.90 & 0.24 & 100.00 \\
\hline
\end{tabular}

